Published in final edited form as:

J Am Chem Soc. 2009 September 09; 131(35): 12497-12515. doi:10.1021/ja9026067.

\title{
Synthesis at the Interface of Chemistry and Biology
}

\author{
Xu Wu ${ }^{*}$ and Peter G. Schultz ${ }^{\dagger},{ }^{*}$ \\ †The Scripps Research Institute, 10550 North Torrey Pines Rd., La Jolla, CA 92037 \\ *Genomics Institute of the Novartis Research Foundation, 10675 John Jay Hopkins Dr., San \\ Diego, CA 92121
}

\begin{abstract}
As the focus of synthesis increasingly shifts from its historical emphasis on molecular structure to function, improved strategies are required to efficiently generate small and large molecules, and even systems of molecules, with defined physical, chemical and biological properties. Given the remarkable array of functions carried out by the molecules found in living organisms, Mother Nature offers both inspiration and help in this regard through an approach to synthesis that seamlessly interfaces biology and chemistry. Here we illustrate the potential of this approach and overview some opportunities and challenges in the coming years.
\end{abstract}

\section{TOC image}

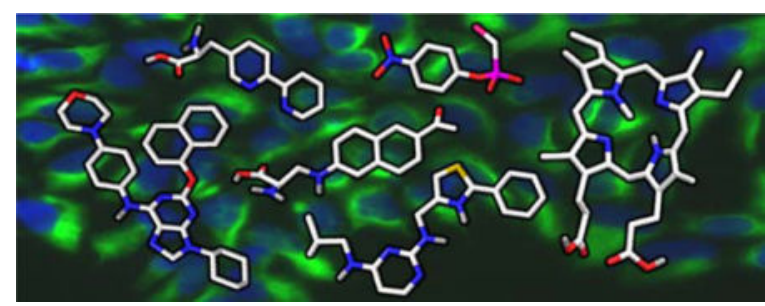

\section{Introduction}

The feature that perhaps most distinguishes chemistry from the rest of the sciences is the ability of chemists to control the structure of matter at the molecular level - from complex natural products like vancomycin to nanoparticles and whole genomes. Indeed, there have been remarkable advances in the fields of total synthesis and synthetic methods over the last fifty years. Unfortunately, we are not nearly as adept at the synthesis of molecules with defined functions as we are at the synthesis of molecules with defined structures. As the focus of chemistry increasingly shifts from structure to function, chemists will need to develop better strategies to efficiently generate molecules, and systems of molecules, with desired physical, chemical, or biological properties in order to meet the biomedical, energy and environmental needs of the future. Indeed this challenge represents one of the great 
opportunities for synthesis in the coming years. One direction we can turn for help is Mother Nature - after all living organisms carry out a remarkable array of complex functions using natural molecules and molecular assemblies, ranging from antibiotics and enzymes to the ribosome and photosynthetic center.

Organic chemists have spent considerable effort synthesizing molecules that attempt to mimic the functions found in Nature. Early examples include functionalized synthetic hosts $^{1,2}$, iron-sulfur clusters ${ }^{3}$ and heme analogues ${ }^{4}$. These efforts attempted to replicate key functions of natural enzymes and receptors, and thereby shed new insights into their molecular mechanisms. As chemists became more sophisticated in their understanding of biomolecules and biological methods, there was an increasing shift in focus to the synthesis of biomolecular mimetics that directly modulate the activities of biological systems themselves. A pioneering example was the synthesis by Dervan and coworkers of polypyrrole-carboxamides that bind DNA in a sequence specific manner much like transcriptional repressors ${ }^{5-7}$ (Figure 1).

But one need not be limited to chemical synthesis alone to generate molecules with novel functions. One can exploit Nature itself, i.e., use the synthetic strategies, molecules and biosynthetic machinery of living organisms together with more traditional chemical approaches to generate molecules with properties that might be difficult to realize by either strategy alone. Such an approach represents a marriage of traditional chemical synthesis with the emerging field of synthetic biology ${ }^{8}$. Early efforts in this direction included the generation of semisynthetic enzymes ${ }^{9}$, ion channels ${ }^{10}$, and metalloproteins ${ }^{11}$ by Kaiser, Erlanger, and Gray, respectively; and the work of Orgel on DNA-directed chemical synthesis ${ }^{12}$. Today this approach is beginning to impact many areas of the chemical, biological and materials sciences. Examples include the biosynthesis of proteins and DNAs from unnatural building blocks ${ }^{13-20}$; combinatorial synthetic strategies inspired by Nature $^{21-25}$; the DNA- or protein-templated assembly of inorganic and organic materials ${ }^{26-29}$; the construction of biohybrid thin films ${ }^{30}$; the use of enzymes in organic synthesis $^{31,32}$; and the generation of orthogonal enzyme-inhibitor pairs ${ }^{33}$. We hope to illustrate the exciting opportunities that exist in synthesis at the interface of chemistry and biology through the examples detailed below, which for reasons of space rather than significance, are derived largely from our own work.

\section{Harnessing Nature's Biosynthetic Machinery}

Nature has developed both templated and nontemplated biosynthetic machinery including the ribosome, DNA and RNA polymerases, polyketide and peptide synthases, and metabolic enzymes to make complex molecules with diverse functions. Moreover, the structure and properties of these molecules can be modified and enhanced by generating large numbers of analogues through mutation, recombination, and amplification, and subjecting them to selective processes. There are an increasing number of examples in which chemists have coopted this natural biosynthetic machinery to create molecules with novel or enhanced functions. For example, the polyketide synthases are large multifunctional enzyme assemblies that consist of modules which encode ketosynthases, acyl transferases, ketoreductases, dehydrogenases and enoyl reductases. Elegant studies by Khosla and others 
have shown that deletion of individual modules, alterations in the activity or specificity of a module, or addition of exogenous building blocks, can lead to new macrolide antibiotics with enhanced activity ${ }^{34-36}$ (which it may in the future be possible to further optimize through directed evolution). Similar strategies are being applied to the synthesis of novel nonribosomal and ribosomal derived peptide antibiotics ${ }^{37,38}$ (Figure 2), secondary metabolites $^{39,40}$, glycopeptides ${ }^{41,42}$, and most recently biofuels ${ }^{43,44}$.

Other efforts focus on the generation of larger biomolecules with altered structures and functions. For example, DNAs are being synthesized in vitro by engineered DNA polymerases that incorporate unnatural base pairs whose thermodynamic stabilities and fidelity of replication begin to rival or exceed those of the Watson-Crick A-T and G-C base pairs ${ }^{17-20}$ (the efficient in vitro and in vivo replication and transcription of modified DNAs or RNAs with these unnatural bases remains a challenge for the future). Sugar and phosphate backbone replacements are also widely used to silence gene expression in vivo ${ }^{45,46}$ and explore DNA structural constraints ${ }^{47}$. Natural proteins are also inspiring the synthesis of designed, folded polypeptides (for example, the work of Degrado, Hodges and Kim on coiled-coils and four helix bundles), and more recently, functional synthetic proteins ${ }^{48-51}$. In addition, a number of laboratories are focused on the synthesis of structurally defined, folded biopolymers entirely from unnatural building blocks (including $\mathrm{N}$-alkyl glycine, and acyclic and cyclic $\beta$-amino acids ${ }^{52-55}$ ) - it may ultimately even be possible to produce these unnatural biopolymers enzymatically by templated synthesis. Of course, the above experiments were made possible by the pioneering work of Merrifield, Khorana and Caruthers that enabled the efficient synthesis of large biological macromolecules ${ }^{56-58}$. In another exciting direction, Bertozzi, Hsieh-Wilson and others have taken advantage of the promiscuity of glycosyl transferases to engineer glycoproteins which contain unnatural carbohydrates with orthogonal chemical handles to allow further chemical elaboration (including modification of cell surfaces) $)^{59,60}$. This approach can also be applied to other protein and nucleic acid modifying enzymes, and has been used to selectively modify proteins with biophysical probes ${ }^{61-63}$. Perhaps in the future such methods will make it possible to control higher order cellular architectures in a defined way.

\section{An Expanded Genetic Code}

In our own work we asked the question whether our molecular understanding and chemical/ biological tools are sophisticated enough to begin to manipulate the genetic code itself, i.e., generate organisms that genetically encode 21 or more amino acids. Although the genetic codes of all known organisms specify the same 20 amino acids (with the rare exceptions of selenocysteine and pyrrolysine), it is clear that many proteins require additional chemistries associated with cofactors and post-translational modifications to carry out their natural functions. Therefore, although the functional groups contained in the 20 amino acid code might be sufficient for life, they might not be optimal. Consequently, the development of a general method that allows us to genetically encode additional amino acids beyond the canonical twenty might facilitate the evolution of proteins, or even entire organisms, with new or enhanced properties. Moreover, the ability to incorporate amino acids with defined steric/electronic properties and chemical reactivity at unique sites in proteins should provide powerful new tools for exploring protein structure and function, much the same way 
physical organic chemists use synthesis to understand the chemical reactivity of small molecules.

Several approaches have been developed to insert unnatural amino acids into proteins. These include the use of intein-based methods for protein semisynthesis by Muir and others ${ }^{64}$ and in vitro and cellular (microinjection) protein translation systems which make use of chemically aminoacylated tRNAs ${ }^{14,15,65-67}$. The latter have been used in detailed molecular studies of protein structure and function, including an impressive study by Dougherty of the mechanism of ion channel gating ${ }^{68}$, and the quantification of the contribution of side chain and backbone $\mathrm{H}$-bonds to protein stability ${ }^{69,70}$. This methodology has even allowed the biosynthetic incorporation of D-amino acids into proteins ${ }^{71}$. However, these methods require the stoichiometric use of the chemically aminoacylated tRNAs which results in relatively low yields of protein ${ }^{14,15}$. Alternatively, a number of in vivo methods have been developed to substitute canonical amino acids in bacteria with unnatural amino analogues ${ }^{16,72-75}$, for example substitute methionine with selenomethionine for phase determination in x-ray crystallography ${ }^{76}$. Perhaps the most elegant of these is that of Tirrell ${ }^{16}$ in which rationally engineered mutations alter the specificity of aminoacyl-tRNA synthetases so that they can incorporate unnatural amino acids (e.g., p-azidophenylalanine, trifluoroisoleucine, etc.) in auxotrophic strains of $E$. coli deficient in the biosynthesis of one of the 20 common amino acids. Although this approach overcomes the historical requirement that the unnatural amino acid be a close structural analogue of a common amino acid (so that it is misacylated by an endogenous aminoacyl-tRNA synthetase), the unnatural amino acid is still substituted for its corresponding canonical amino acid at all such sites throughout the proteome (i.e., one replaces one of the canonical twenty amino acids with an analogue, one does not add a new amino acid to the code). In addition, the use of auxotrophic strains can lead to partial incorporation of the unnatural amino acid in competition with endogenous amino acids. Nonetheless these methods have found many exciting applications in the generation of novel biomaterials ${ }^{77}$, the surface immobilization of proteins ${ }^{78}$, the selective labeling of proteins with biophysical probes ${ }^{16,79}$, and the like.

The challenge we undertook was to develop a general method that makes it possible to expand the genetic code, i.e., incorporate additional amino acids (beyond the common twenty) uniquely at any genetically specified site in a protein with the same high translational fidelity and efficiency characteristic of natural protein biosynthesis. The incorporation of additional amino acids into proteins directly in a living organism requires a unique tRNA:codon pair, a corresponding aminoacyl-tRNA synthetase and significant intracellular levels of the unnatural amino acid ${ }^{13}$ (Figure 3). First, the unnatural amino acid must be efficiently transported into the cytoplasm when added to the growth medium, or biosynthesized by the host, and it must be stable in the presence of endogenous metabolic enzymes (most unnatural amino acids meet these criteria). Next, to ensure that the unnatural amino acid is incorporated uniquely at the site specified by its codon, a tRNA must be constructed such that it is not recognized by the endogenous aminoacyl-tRNA synthetases (aaRS) of the host (21 in E. coli), but functions efficiently in translation (an orthogonal tRNA). Moreover, this tRNA must deliver the novel amino acid in response to a unique codon that does not encode any of the common 20 amino acids. This codon can be either one of the degenerate stop codons (e.g., an amber nonsense codon) or an efficient four base 
frameshift codon. Another requirement for high fidelity is that the cognate aminoacyl-tRNA synthetase (an orthogonal synthetase) aminoacylates the orthogonal tRNA, but does not aminoacylate any of the endogenous host tRNAs (86 in E. coli). Furthermore, this synthetase must aminoacylate the tRNA with only the desired unnatural amino acid, and not with any of the large number of endogenous amino acids of the host organism. Similarly, the unnatural amino acid cannot be a substrate for the endogenous synthetases if it is to be incorporated uniquely in response to its cognate codon. This set of severe specificity requirements represented the major synthetic challenge to the successful development of this methodology.

Fortunately, we have atomic resolution structures of virtually the entire protein translational machinery 80,81 , so that the creation of new components with the requisite specificities is largely a molecular (chemical) problem. In brief, it was known that for certain isoacceptor tRNAs, the identity elements of tRNAs from bacteria, archaea and eukaryotes differ ${ }^{82}$ so that in theory one could import a tRNA/aminoacyl-tRNA synthetase pair from archaea that would be functionally orthogonal in $E$. $\operatorname{coll}^{83}$. This proved not to be the case when an archael tRNA ${ }_{\mathrm{CUA}}^{\mathrm{Tyr}}$ was imported into E. coli, so a large library of tRNA mutants was generated based on a consensus sequence analysis and a general, two step positive and negative selection scheme was developed to identify from this library orthogonal tRNA/ aaRS pairs ${ }^{84}$. This strategy has proven a general approach for generating orthogonal tRNA/ aaRS pairs; more recently, such pairs have also been generated from pyrrolysine derived aminoacyl-tRNA synthetases ${ }^{85-87}$. To alter the substrate specificity of the orthogonal aminoacyl-tRNA synthetase so that it recognizes an unnatural amino acid and not any endogenous amino acids, a large, directed library ( $10^{9}$ mutants) of active-site mutants was generated and subjected to a combination of positive and negative selections to identify a synthetase with the desired specificity ${ }^{88}$ (Scheme I). The positive selection is based on chloramphenicol resistance, which is conferred by the suppression of an amber mutation at a permissive site in the chloramphenicol acetyltransferase gene only in the presence of the unnatural amino acid. The negative selection uses the toxic barnase gene with amber mutations at permissive sites and is carried out in the absence of the unnatural amino acid to eliminate aaRS mutants that aminoacylate endogenous amino acids.

This selection scheme and more facile variants have been used to develop aaRS mutants that are capable of selectively inserting one or more unnatural amino acids into proteins in E. coli in response to nonsense and/or four base frameshift codons ${ }^{89}$ in good yields $(5 \mathrm{mg} / \mathrm{L}$ to $\sim 1$ $\mathrm{g} / \mathrm{L}$ ) and with high translational fidelities which rival those of natural protein biosynthesis (although context effects do influence the efficiency and fidelity of incorporation at specific sites and is an obvious challenge for future methodological improvements). This system has been expanded to both yeast and mammalian cells by ourselves as well as the laboratories of Yokoyama and Wang ${ }^{90-99}$. Experiments are now underway to generate a synthetic yeast in which degenerate codons are freed up to encode unnatural amino acids, and to create transgenic worms and mice encoding a $21^{\text {st }}$ amino acid of choice. We have also successfully "synthesized" an autonomous 21 amino acid bacterium that both biosynthesizes and genetically encodes the unnatural amino acid $p$-aminophenylalanine ${ }^{100}$ - it will be of interest to compare its evolutionary fitness to that of wildtype $E$. coli. 
Approximately 50 unnatural amino acids with novel chemical, biological and physical properties have been genetically encoded ${ }^{13,101}$ (Figure 4). These include heavy atom containing amino acids to facilitate $\mathrm{x}$-ray crystallographic studies ${ }^{102,103}$; amino acids with novel steric/packing and electronic properties ${ }^{99,104,105}$; photocrosslinking amino acids which can be used to probe protein-protein and protein-nucleic acid interactions in vitro or in vivo ${ }^{106-110}$, or to identify orphan ligands/receptors; keto, diketo, acetylene, azide, thioester, boronate, long chain thiol and dehydroalanine containing amino acids that contain functional groups with unique chemical reactivity which can be used to site-specifically introduce a large number of biophysical probes, tags, toxins and novel chemical functional groups into proteins in vitro or in vivo (both intracellular and cell surface proteins), or to generate intra- or intermolecular crosslinked proteins and/or peptides ${ }^{111-117}$; redox active amino acids to modulate electron transfer in proteins ${ }^{118-120}$; photocaged and photoisomerizable amino acids to photoregulate cellular processes ${ }^{121-125}$ such as signal transduction, protein trafficking and transcription; metal binding amino acids for catalysis, self-assembly, $x$-ray phasing and in vivo imaging (Figure 5) ${ }^{102,120,126,127}$; amino acids that contain NMR probes, or fluorescent or IR active side chains as local probes of protein structure and dynamics in vitro and in vivo ${ }^{128-135}$ (Figure 5); a-hydroxy acids and D-amino acids as probes of backbone conformation and hydrogen bonding interactions ${ }^{136}$ (raising the intriguing possibility of making folded "polyester" proteins); and sulfated amino acids and mimetics of phosphorylated amino acids as probes of protein posttranslational modifications ${ }^{137,138}$. Clearly this list can likely be expanded to include many additional amino acids with novel chemical, physical, and biological properties. Importantly we have solved the x-ray crystal structures of a number of these mutant aminoacyl-tRNA synthetases, and they reveal active sites with a high degree of plasticity as evidenced by significant alterations in both active site side chains and the polypeptide backbone to create new van der Waals packing and hydrogen bonding interactions with the bound unnatural amino $\operatorname{acid}^{139,140}$.

Applications of these unnatural amino acids include the generation of therapeutic proteins with enhanced pharmacology (a long-lived, selectively pegylated human growth hormone made by Ambrx is in phase II clinical trials and is produced on greater than a $1000 \mathrm{~L}$ scale) - indeed this methodology promises for the first time to allow medicinal chemistry-like control over the structures of proteins to produce homogenous therapeutic agents ${ }^{141}$. This is in contrast to the historical, relatively nonspecific methods for the chemical modification of therapeutic proteins with electrophilic moieties ${ }^{142}$, or the selective modification of cysteine residues which is often complicated by the presence of multiple cysteines and/or their involvement in protein folding (e.g., immunoglobulins). Other recent examples include: (2) the use of p-nitrophenylalanine mutants to break immunological self-tolerance and generate robust, long-lasting T- and B-cell mediated immune responses that cross react with wildtype proteins. This method for increasing the immunogenicity of self-proteins or weakly immunogenic pathogen proteins is currently being applied to the development of cancer and antiviral vaccines ${ }^{143}$. Indeed the demonstration that simple nitration of phenylalanine at one site in a protein can break tolerance through $\mathrm{T}$ cell-mediated mechanisms suggests that the posttranslational generation of nitrotyrosine in proteins through local inflammation and cytokine release may be a general underlying initiating event in autoimmune disease ${ }^{144,145}$; 
(3) the use of photocaged amino acids to photoactivate protein phosphorylation and subsequent transport in living cells in a temporally and spatially defined fashion ${ }^{123}$; (4) the generation of immunotoxins, antibody-DNA conjugates (immuno-PCR), bispecific antibodies, and carrier-peptide conjugates with enhanced pharmacokinetics or targeted activities $^{93}$; (5) the use of environmentally sensitive, fluorescent amino acids (e.g., Prodan, dansyl and 5-hydroxy coumarin side chains) for in vitro and cellular imaging of protein localization, biomolecular interactions and conformational changes with the ability to place these small probes at virtually any site in the proteome ${ }^{132,146,147}$; (6) the use of metal ion binding amino acids (e.g., bipyridyl and hydroxyquinoline side chains) to introduce oxidative and hydrolytic catalytic activities into proteins (either by selection or design) without the need to organize complex primary and secondary metal ion binding shells ${ }^{148}$; (7) the use of redox amino acids as mechanistic probes of electron transfer in enzymes ${ }^{119}$, isotopically labeled amino acids as IR probes of protein dynamics, and sterically modified amino acids as probes of ion channel activation ${ }^{99}$; and (8) the use of photocrosslinking amino acids to map biomolecular interactions in cells and identify orphan ligands and receptors ${ }^{149-151}$.

In addition, we are beginning to examine the influence of an expanded genetic code on the evolution of peptides and proteins with new or enhanced properties. For example a modified phage display system was used to evolve germline antibodies (with a randomized $\mathrm{V}_{\mathrm{H}} \mathrm{CDR} 3$ loop NNK library, where $\mathrm{N}=\mathrm{A}, \mathrm{G}, \mathrm{C}, \mathrm{T}$ and $\mathrm{K}=\mathrm{G}$ or $\mathrm{T}$ ) in strains that genetically encode sulfotyrosine or $p$-boronophenylalanine. We found that sulfotyrosine and $p$ boronophenylalanine-containing Fab fragments emerged over all other clones in selections for gp120 and glucamine binding, respectively. In both cases, the selected mutant proteins utilized the unnatural amino acid to outcompete the other variants in the initial library, most of which only contained the 20 natural amino acids ${ }^{152,153}$. These results suggest that it may be possible to evolve antibodies with enhanced binding affinities to glycoproteins, serine proteases, metalloenzymes and the like by incorporating amino acids with novel functional groups (hydroxamates, boronates, keto groups, etc.). A similar approach is now being applied to the synthesis and selection of acyclic and cyclic ribosomal peptides containing unnatural amino acids. It is likely that one can also either rationally design or evolve proteins with enhanced catalytic activities using an expanded genetic code (e.g., introduce transition metal binding sites to create new catalytic activities). It may even be possible to evolve novel folds from randomized codon libraries which encode both the canonical twenty, as well as unnatural amino acids. The generation of orthogonal ribosomes by Chin and coworkers also promises to increase the diversity of unnatural biopolymers that can be translated by allowing mutations to the ribosome that do not affect the entire proteome ${ }^{154}$. Thus by seamlessly integrating the complex translational machinery of living cells with new chemistries and in vitro evolution methods, we have overcome a billion year constraint imposed by the universality of the genetic code. This advance may allow the generation of proteins and perhaps even living organisms with novel or enhanced properties, and underscores the power of co-opting (rather than mimicking) Nature to create novel new functions. 


\section{Molecular Diversity - Nature's Synthetic Strategy}

Another example of the synergy between chemistry and biology in the generation of molecules with novel functions is the development and application of diversity-based synthetic strategies. This approach, which was inspired by Nature, involves the generation of large collections or "libraries" of molecules that are subsequently screened or selected based on function. Indeed this represents one of living organisms' most powerful strategies for synthesizing molecules with desired properties. For example, the humoral immune system has developed highly sophisticated combinatorial and mutational mechanisms for generating large libraries of antibodies and selecting those that can recognize foreign antigens with high affinity and selectivity ${ }^{155}$ (Figure 7). The notion that this natural diversity can be used to create novel chemical function was first illustrated with the generation of catalytic antibodies ${ }^{156-159}$. Rather than attempting to $a b$ initio generate enzyme-like catalysts from synthetic hosts, which was the popular approach at the time, it was realized that one could simply co-opt the immune system to generate a highly selective natural host in the form of an antibody combining site. To generate a selective catalyst rather than a selective receptor, stable transition state analogues (rather than substrates) were used as antigens on the basis of the Pauling notion ${ }^{160}$ that enzymes evolve maximum binding affinity to the transition state of a reaction. The early experiments by Lerner and in our own laboratory involved the generation of esterolytic antibodies using phosphonate/phosphate transition state analogues 156,157 . Other approaches have since been developed to generate catalytic antibodies including covalent catalysis, proximity effects, and general acid-base catalysis ${ }^{22}$ (thereby allowing us to dissect the contribution of each of these factors to biological catalysis). Using these approaches, antibodies have been generated that catalyze a wide array of chemical reactions, from acyl transfer and redox reactions to pericyclic and photochemical reactions with specificities and in some cases rates rivaling those of enzymes $^{22,161,162}$. For example, Lerner and Barbas used mechanism-based selections to generate antibodies that catalyze aldol reactions through covalent catalysis with catalytic efficiencies and selectivities remarkably similar to those of the Class I adolases ${ }^{163}$ (Figure 8). Indeed one such antibody has made its way into clinical trials as a carrier for therapeutic peptides, which are bound covalently to the catalytic lysine residue. At the same time, mechanistic studies of this aldolase antibody led these investigators to the discovery that the simple amino acid proline could act as an asymmetric organocatalyst ${ }^{164,165}$. Antibodies have also been generated to catalyze "difficult" chemical transformations such as kinetically disfavored exo Diels-Alder and anti-Baldwin cyclization reactions ${ }^{166}$.

The detailed characterization of the immunological evolution, three dimensional structures and mechanisms of catalytic antibodies are also helping to dissect and quantify the relationship between binding energy and catalysis in the evolution of catalytic function. Indeed, the use of transition state analogues to elicit catalytic antibodies provided "proof by synthesis" of the Pauling notion of enzymatic catalysis. In another example a "ferrochelatase" antibody, which catalyzes the efficient insertion of metal ions into porphyrin (the last step in heme biosynthesis), was generated against a distorted $\mathrm{N}$-methyl protoporphyrin, which mimics the distorted porphyrin ring of the putative transition state for metallation ${ }^{167}$. The crystal structure of the Michaelis complex (Figure 9) ${ }^{168}$ indeed showed 
that the substrate is bound in a strained conformation - providing the first direct structural evidence for the theory of substrate strain proposed by Haldane over 70 years ago.

The characterization of catalytic antibodies has also provided fundamental insights into the mechanisms by which the immune system itself evolves selective receptors. For example, the first detailed structural comparisons of germline and affinity-matured antibodies revealed the critical role of structural plasticity (in addition to genetic diversity) in determining the tremendous binding potential of the germline antibody repertoire ${ }^{169-171}$ (Figure 10). Germline antibodies appear to have a high degree of intrinsic combining site conformational flexibility (reminiscent of the chemical instruction theory of the immune response proposed by Haurowitz and Pauling ${ }^{172}$ ) which allows them to bind distinct ligands in different conformational states ${ }^{173}$. These states are then locked by somatic mutations which occur during affinity maturation (not protein folding as proposed by Pauling). Structural and biophysical analyses of the immunological evolution of catalytic antibodies also pointed to the critical role of mutations distal to the active site in controlling the binding and catalytic activity of proteins ${ }^{174}$. Indeed these studies underscore a key aspect of diversity-based synthetic strategies - detailed analysis of the relationship of molecular structure and properties in molecules obtained by combinatorial methods (properties which may be difficult to obtain by more conventional synthetic approaches) often lead to new chemical insights which further increase our ability to generate new molecular function from basic chemical principles.

The demonstration that the vast structural diversity of antibody molecules can be redirected with the proper chemical instruction to generate selective catalysts illustrated the utility of molecular diversity (the antibody repertoire in this case) as a new, biologically-inspired "synthetic strategy" to create novel chemical properties. Shortly thereafter, libraries of other biomolecules were designed and synthesized in order to identify molecules with new or enhanced functions. These included the use of phage display libraries ${ }^{23}$ to generate peptides, proteins and antibody fragments with novel specificities - for example a peptide dimer with erythropoietin-like activity ${ }^{175}$, zinc finger proteins with new DNA binding specificities ${ }^{176-178}$, and more recently, polypeptides that template inorganic materials ${ }^{179}$. An example of the latter involves the selection of peptides that specifically bind semiconductors to direct nanoparticle assembly ${ }^{180}$. Libraries of carbohydrates have also been generated ${ }^{181}$; and libraries of random RNA sequences (including those containing unnatural bases with novel functional groups) have been transcribed and subjected to in vitro selections to identify RNAs (aptamers) that selectively bind ligands with high affinity (aptamers) ${ }^{182,183}$, that catalyze chemical reactions such as acyl or phosphoryl transfers ${ }^{184-186}$, or whose structure and transcription is regulated by the binding of small synthetic molecules ${ }^{187}$. Indeed it may even be possible to use diversity based approaches to construct completely synthetic viruses (e.g., small RNA viroids that do not encode proteins) that target specific cell types, or even self-replicating systems of molecules ${ }^{188-190}$. In addition, combinatorialbased diversity approaches such as DNA shuffling (in which positively selected point mutants are recombined to yield additive improvements in function) are also being used to evolve proteins with new catalytic activities, specificities and regulation ${ }^{191}$. The inherent somatic mutation machinery of the B cell itself has also been harnessed to evolve fluorescent proteins with enhanced photophysical properties ${ }^{192}$. Random libraries of amino acids or 
secondary structural elements have even been created to identify minimalist and novel protein folds ${ }^{193-196}$. Diversity based approaches are also being used to create synthetic biological circuitry in which a defined input is biologically processed to give a specific output (e.g., bacteria migrate to illuminated regions of a plate, or a binding event initiates enzymatic amplification of a specific signal ${ }^{197,198}$. In related experiments cellular complementation strategies are being used to evolve enzymes for the in vivo manipulation of biomolecules ${ }^{199}$. Finally, libraries of peptides, oligonucleotides and unnatural biopolymers provide a powerful approach to identify molecules that facilitate the trafficking of therapeutic small molecules, polypeptides, DNAs and siRNAs across cellular, endosomal and intestinal membranes - a major challenge in medicine ${ }^{200-202}$. These various applications are beyond the scope of this perspective but represent important new directions for synthesis at the interface of chemistry and biology.

\section{Applications of Molecular Diversity to Chemistry}

\section{Materials Science}

Today, combinatorial strategies, which in their most basic form involve the parallel synthesis of large numbers of chemically diverse structures around a central framework (typically chosen on the basis of theoretical or empirical considerations), are impacting many areas of chemistry $^{21}$. This method is particularly valuable when theory has insufficient predictive power to guide molecular design with precision - it quickly provides large amounts of experimental data around initial candidate structures to either iterate with theoretical predictions or develop improved models to guide additional experiments. One particularly illustrative example of how a synthetic concept, adopted from the natural processes of mutation, recombination and selection, can impact a very distinct scientific discipline is the application of diversity-based approaches to the generation of solid-state materials with novel properties ${ }^{203-207}$. The properties of many functional materials, such as hightemperature superconductors, heterogeneous catalysts, ferroelectric materials, magnets, and even structural materials arise from complex interactions involving the host structure, dopants, defects, and interfaces, all of which are highly dependent on composition and processing. Unfortunately, our current level of theoretical understanding does not generally allow one to predict the structures and resulting properties of these materials. The situation is further complicated by the complex compositions of many modern materials (four or more elements) and the fact that materials synthesis, unlike organic synthesis, is generally not a kinetically controlled process. Given the large number of elements in the periodic table that can be used to make compositions consisting of up to six elements, the universe of possible new compounds with interesting physical and chemical properties remains largely unexplored; combinatorial synthetic methods represent a powerful way for experimentalists and theorists alike to more effectively mine this huge chemical space for interesting new materials properties ${ }^{208-211}$.

The first application of combinatorial methods to materials science involved the synthesis and screening of libraries of thin-film copper oxides to identify high-temperature superconductors ${ }^{203}$. Libraries of solid state materials were synthesized to explore many different compositions of interest by sequentially sputtering precursors at different sites on a 
substrate using a series of precisely positioned shadow masks. Low-temperature annealing followed by high-temperature processing resulted in the formation of superconducting thin films. More recently, quaternary and shutter masking systems, together with photolithographic masking techniques and pulsed laser deposition, have made possible the synthesis of high-quality, diverse thin-film libraries of some 1,000 to 10,000 samples (Figure 11). We and others have used such libraries to discover phosphors with novel luminescent properties and structures, new families of giant magnetoresistive materials and ferroelectric materials ${ }^{203-206}$. Solution-based and bulk methods (e.g., ball milling) have also been applied to materials and catalyst library synthesis ${ }^{212}$ (and in an interesting twist have been used to explore phase diagrams for crystalline proteins ${ }^{213}$ ). In addition a large number of scanning or parallel detection systems have been developed for rapidly screening materials libraries for optical, electronic, magnetic, adsorptive or catalytic properties of interest. This combinatorial approach to materials discovery, which was dramatically expanded in scope by Weinberg and coworkers at Symyx, is now practiced in many industries and has led to new olefin polymerization and oxidative catalysts, hydrogen storage materials, separations materials, dielectrics, phosphors, and is now being applied to the optimization of complex integrated electronic devices such as lithium ion batteries, solar cells and computer chips $^{207-212,214-217}$. Indeed with the challenges we now face for new environmentally friendly energy sources, combinatorial methods are likely to play a critical role in the development of enabling new materials - these include new hydrogen and methane storage materials, fuel cell catalysts, photovoltaic devices, $\mathrm{CO}_{2}$ sequestrants, and high energy density battery electrodes. This will be likely best achieved by a synergistic use of combinatorial approaches, more conventional solid state chemistry and theory.

\section{Biologically Active Small Molecules}

Another particularly powerful application of combinatorial strategies, first pioneered by Ellman and coworkers with his work on benzodiazepines, involves the synthesis of diverse libraries of nonoligomeric synthetic molecules $24,218,219$. Just as large libraries of antibodies are genetically assembled from families of V, D and J gene segments, it was realized that libraries of small organic molecules could be efficiently assembled from chemical building blocks. And although there are many examples of the rational design of biologically active small molecules (outstanding examples include mechanism-based inhibitors by Bloch ${ }^{220}$, reporters of cellular messengers by Tsien 221 , and the synthesis of captopril and Prozac by chemists at Squibb and Eli Lilly, respectively ${ }^{222,223}$ ), it remains a challenge to a priori design molecules that selectively activate or inhibit a desired enzyme or receptor, or modulate a specific cellular signaling pathway, regulatory circuit or transcriptional program. As a consequence, the screening of synthetic chemical libraries offers a highly effective approach to identify biologically active molecules, especially molecules with novel, or even unprecedented, cellular activities (which may not be predicted, or even conceived of in hypothesis-driven experiments). Chemical leads from these screens can then form the basis for further chemical optimization experiments (including structure-based design), just as natural products have long inspired medicinal chemists in the synthesis of new drugs. The real challenge for chemists here is not chemical synthesis itself, but rather the creation and integration of well-designed chemical libraries with creative cellular screens and screening strategies (transcriptional, pathway, image-based and phenotypic screens) to find molecules 
that modulate biological systems in interesting and/or useful ways, and the subsequent characterization of their mechanisms of action.

In particular, combinatorial strategies allow one to assimilate large libraries (>100,000 molecules) of diverse molecular structures relatively easily and inexpensively (in contrast to the historical large collections of synthetic compounds and natural products that were found almost exclusively in large pharmaceutical companies). In addition, high throughput screening systems in which compound libraries can be screened in parallel in biochemical or cellular assays in $<10 \mu \mathrm{L}$ volumes (and in almost any format from FRET and ELISA assays to luminescent and high-content imaging screens) have reduced the cost of assays (as well as the amount of compound required) from dollars per data point to pennies per data point, making small molecule screens a viable research tool for many academic laboratories ${ }^{224,225}$. Recent advances in micro- and nanofluidics and dispensing technologies have further miniaturized the screening format ${ }^{226}$; and automated cell culture systems in which $100+$ cell lines can be passaged, plated and assayed in a completely automated fashion, allow massively parallel screening of protein families for selective ligands (Figure 12) 224 . As a consequence the number of small molecules that modulate protein or RNA targets, or cellular pathways will grow enormously in the next 5-10 years. Indeed the screening database at the Genomics Institute of the Novartis Research Foundation (GNF) now exceeds 500 million data points allowing one to rapidly correlate the activity of "hits" from any given screen to hundreds of other cell-based or biochemical screens to determine selectivity and/or potential cellular pathways that are affected through cluster analysis. For example, screening of $>2$ Mio molecules in a Plasmodium falciparum proliferation assay in red blood cells yielded $\sim 8,000$ active compounds which had antimalarial activity and minimal activity against human cells ${ }^{227}$. Cluster analysis revealed a number of novel scaffolds that targeted both known and novel biochemical pathways and were active against mutant strains. Novel chemoinformatic tools and data mining efforts will likely yield important insights into biological networks in the coming years.

Since it is impossible to represent all chemical space corresponding to low molecular weight (LMW) compounds ( $<500$ daltons), various arguments have been put forth regarding the structural motifs that should be represented in chemical libraries - from complex natural product-like molecules ${ }^{228-230}$ to heterocycles such as purines, benzimidazoles, indoles, quinolines ${ }^{231}$ and other "privileged" scaffolds ${ }^{232}$ (Figure 13). The latter have the advantage that they have historically yielded biologically active molecules that selectively modulate the activities of enzymes, GPCRs, nuclear receptors, ion channels and the like. Moreover, they can be rapidly synthesized and there exists a wealth of information on the pharmacology of these scaffolds - which is critical to the chemical optimization of these structures for in vivo studies. Indeed, our experience is that these heterocycle libraries are an extremely rich source of selective and potent hits (in both cellular and biochemical assays) whose properties can be rapidly optimized.

One can ask the question why should academic laboratories screen small molecule libraries for novel biological activities given that this activity has historically been the focus of the pharmaceutical and biotechnology industries. Arguments have been made that unbiased cellbased screens of small molecules offer an alternative to genetic approaches to identify novel 
genes associated with a cellular phenotype ${ }^{233,234}$. Indeed, novel gene products have been identified from synthetic molecules and natural products - the identification of FK506 binding protein independently by Schreiber and the Merck group using affinity-based methods represents one outstanding example ${ }^{235}$. However, the lack of selectivity and weak potency of many primary screen hits (in comparison to natural products), need for structureactivity relationship information (historically provided by pharma) to optimize activity and generate affinity probes, and the complexities associated with either genomic (mRNA expression analysis, cDNA overexpression) or proteomic (phosphoprotein profiling and protein affinity arrays) target deconvolution make this approach challenging even for laboratories with considerable chemical and biological expertise. The availability of genome-wide cDNA, siRNA or shRNA, and non-coding RNA libraries in transfectable or retro/lentiviral format provides a more straightforward approach to identify new gene function that requires no deconvolution and is generally far more selective in targeting a specific gene ${ }^{236-238}$. However, as improved methods for identifying the targets and mechanisms of biologically active small molecules are developed, cellular screens of chemical libraries will become increasingly important in cell biology ${ }^{239}$. Indeed, such methods represent probably the most significant current challenge to the effective use of cell-based small molecule screens to discover novel biology.

Nonetheless, cell-based screens of small molecule libraries have a distinct advantage in that they allow one in a single experiment to interrogate large numbers of interacting proteins and nucleic acids (many with unknown function) in an unbiased fashion to identify synthetic molecules that affect biological systems in novel ways. Furthermore, in contrast to most genetic methods, small molecules are able to perturb specific functions of a single protein (or multiple proteins) with temporal control, and without affecting its other activities, which is an especially useful feature for dissecting signaling pathways where proteins often serve both catalytic and recruitment functions that cannot be addressed independently with genetic approaches. Indeed, the power of cell-based screens dates back to the pioneering studies of Paul Ehrlich in which he identified synthetic arsenicals that selectively killed syphilis ${ }^{240}$. This cell biological approach was largely displaced by biochemical target based approaches, but with large chemical libraries, modern, highly sensitive screening and imaging technologies, and genomic and proteomic target deconvolution strategies cellular screens once again offer a powerful strategy for finding synthetic molecules with novel biological and potentially therapeutic activities.

Another real advantage of the small molecules derived from such screens is that they can be relatively quickly translated to primary cells and in vivo models to test biological hypotheses in the complex setting of whole organism physiology (without the need to generate knockout or transgenic animals, or use viral gene or siRNA delivery) - ultimately with the hope of finding new medicines that operate by novel mechanisms. To do so, however, requires a knowledge of basic medicinal chemistry and pharmacology to optimize the properties of molecules including but not limited to potency, selectivity (indeed, most molecules isolated from screens lack high selectivity), metabolic stability, bioavailability, serum half-life and $\mathrm{C}_{\max }$, blood-brain barrier penetration, biodistribution, etc. ${ }^{241}$. This aspect of "chemical biology" has been largely ignored or less explored by many in the academic research community - an oversight that must be remedied if we are to realize the full biomedical 
value of the molecules that will result from such screening activities (indeed, it is likely that we will see a large increase in the number of therapeutic agents resulting from academic efforts as chemists become more sophisticated in in vitro and in vivo pharmacology, animal models, and cell biology).

Given the increased availability and decreased cost of libraries and the power of modern screening technologies, what opportunities should the academic chemistry community pursue with these new tools? One direction is to focus our efforts on those areas of biology which are still poorly understood, where a real need and desire for pharmacologically active small molecules exists, and which have been largely ignored by industrial research efforts, but nonetheless represent major unmet medical needs. A timely example is regenerative medicine in which new cells (e.g., neurons, muscle, chondrocytes) are generated to replace tissues lost to degenerative diseases or aging (small molecules offer an alternative to cellbased therapies or gene therapy which carry with them the possibility of developing cancers). To this end, we have been carrying out cell-based screens to identify molecules that: (1) control the self-renewal or lineage specific differentiation of adult and embryonic stem cells (cells with the capacity to self-renew or differentiate into specialized tissues), and (2) that control the proliferation or reprogramming of differentiated cells ${ }^{242-249}$. For example, we have carried out image-based screens (using cellular markers such as CD34, CD133, CD41, etc.) with one class of adult stem cells, hematopoietic stem cells, or HSCs (which give rise to all the blood cell lineages) for molecules that control HSC self-renewal and differentiation. Molecules have been identified that induce the selective differentiation of human HSCs toward megakaryocytes; molecules have also been found that are able to significantly expand both human peripheral mobilized HSCs and umbilical cord blood HSCs in an undifferentiated state such that they efficiently engraft in a NOG mouse model and give rise to all blood cell lineages ${ }^{250}$. The latter molecules represent a new regenerative drug to expand cord blood HSCs for the large number of cancer, blood and autoimmune disease patients for which no matched donors exist, but for which matches do exist in cord blood banks. In other experiments with adult stem cells, we have used cell-based screens, coupled with immunostaining of neuronal markers to identify molecules that induce the selective neurogenesis of neural progenitor cells in vivo in the rat dentate gyrus by binding the centrosomal protein Tacc3 (which has been previously implicated in regulating the balance between progenitor cell renewal and differentiation ${ }^{251,252}$ ). We have also used alkaline phosphatase and Alcian blue-based screens to identify molecules that selectively induce mesenchymal stem cells (adult stem cells which normally give rise to osteoblasts, adipocytes and chondrocytes) to undergo osteogenesis to form bone (by activating Hedgehog signaling - a key developmental pathway) or chondrogenesis to form cartilage (with the potential to treat early stage osteoarthritis), based on analysis of multiple tissue specific markers, cellular morphology and the like (Figure 14) 253,254 . Other laboratories have also recently identified small molecules that modulate stem cell fate. Examples include molecules that suppress osteoclastogenesis; enhance differentiation of osteoprogenitor cells to increase bone formation; affect myocardium repair; and modulate the neuronal differentiation of stem cells ${ }^{255-261}$. In addition, small molecule agonists and antagonists of important developmental signaling pathways (Wnt, Hh, BMP, etc.) have been discovered, and are serving as important tools to study stem cell biology and cancer ${ }^{262-266}$. Many additional 
exciting opportunities exist for chemists with adult stem cells including screens for molecules that expand satellite cells, endothelial progenitors or neural stem cells for muscular dystrophies, cardiovascular repair, neurodegeneration, and the like. One can also attempt to identify molecules that selectively induce apoptosis or differentiation of cancer stem cells which have been implicated in a number of different cancers (stem-like cells from which bulk tumors are thought to arise and which are often resistant to chemotherapies) ${ }^{267}$. For example, we have identified small molecules that kill prostate tumor initiating cells by blocking the PI3K signaling pathway ${ }^{268}$. In combination with the antitumor drug Taxotere, this inhibitor is extremely effective in regressing established tumors in a mouse xenograft model.

One can also screen for molecules that affect the self-renewal or differentiation of embryonic stem cells. For example, OCT4-green fluorescent protein (GFP) (OCT4 is a gene expressed in embryonic stem cells, ESCs) and ANF-luciferase (atrial natriuretic factor, $A N F$, is a cardiomyocyte specific marker) transcriptional reporter screens have been used to identify small molecules that allow one either to expand ESCs in an undifferentiated state $^{269}$, or induce their differentiation to cardiomyocytes ${ }^{270}$, respectively. In the former case affinity-based methods showed that the molecule acts by binding both RasGAP and Erk1/2 and thereby modulating both cell proliferation and differentiation (this was confirmed by both abrogating the activity of the compound by overexpressing cDNAs for both genes, or independently knocking down the activity of each gene with siRNAs or chemical inhibitors) ${ }^{269}$. In another example we identified a molecule that potentiates ESCs to differentiate into ectodermal, mesodermal or endodermal lineages (depending on the additional lineage specification factors present) in high yield in chemically defined media. This molecule functions by binding and blocking the nuclear translocation of the protein NME2, which leads to downregulation of c-Myc - a key ES self-renewal regulator and oncogene (Figure 15) ${ }^{271}$. In a related series of experiments by Melton and coworkers, it was recently shown that two small molecules (IDE1 and IDE2) can selectively induce human ESCs to differentiate into definitive endoderm ${ }^{272}$, and subsequent treatment with (-)indolactam $\mathrm{V}$ can further mature the definitive endoderm cells to pancreatic progenitor cells ${ }^{273}$. Combinations of molecules of this sort may facilitate the generation of hepatocytes, endocrine and other cell types from ESCs in high yield under chemically defined conditions. One can also expand these activities beyond small molecules and screen libraries of purified, secreted proteins and peptides (the majority of which have unknown functions) to identify circulating polypeptides that affect stem cells in novel ways. In one example, we recently identified the protein pigment epithelium derived factor that allows one to expand huESCs in defined media ${ }^{274}$.

Another exciting direction in the field of regenerative medicine is the reprogramming of somatic cells ${ }^{247}$, both to create cellular models of genetic disease, and potentially cells for clinical use in regenerative therapies. Recently, it was shown by Yamanaka and coworkers that the overexpression of four genes (Oct4, Sox2, c-Myc and Klf4) in mouse embryonic fibroblasts (MEFs) or human fibroblasts reverts them to embryonic stem-like cells (termed induced pluripotent stem, or iPS cells) that can then differentiate into all three germ layers ${ }^{275-279}$. Clearly the identification of drug-like small molecules with such activities might allow one to create desired cell types (e.g., those lost to degenerative disease - 
neurons, $\beta$-cells, etc.) from other tissues patient specifically, without the need for nuclear transfer or embryonic stem cells. For example, we have identified a molecule (reversine) that can reprogram myoblasts (muscle progenitor cells) to a multipotent state which can then be differentiated into adipocytes (fat cells) or osteoblasts (bone cells) (Figure 16) ${ }^{280,281}$. Clonal analysis demonstrated reprogramming rather than side population artifact, and the relevant targets of reversine were found to be MEK1/2 and non-muscle myosin II. Similarly, molecules have been identified that reprogram oligodendrocyte precursor cells (which normally give rise to glial cells in the brain) to neural stem-like cells, such that they can be further converted to neurons and function in vivo ${ }^{282,283}$. Many laboratories are now attempting to identify molecules that replace single factors or combinations of factors to generate iPS cells (in our case using a Nanog promoter driven luciferase reporter which allows >2 Mio compounds to be efficiently screened) - indeed we have identified molecules that independently replace Sox 2 and Klf4 in reprogramming of mouse embryonic fibroblasts ${ }^{282}$. Others have also demonstrated that small molecules inhibitors of histone modification (methylation, deacetylation) and DNA methylation, agonists of L-type calcium channels, and kinase inhibitors (TGF $\beta$ receptor, GSK3 $\beta$ or MEK) can enhance reprogramming efficiency, replacing certain genetic factors in generating iPS cells or maintaining rat iPS cells ${ }^{279,284-287}$. Future efforts in this regard will likely include screens for small molecules that reprogram pancreatic exocrine cells or hepatocytes to insulin producing $\beta$-cells and the like.

One can also ask whether one can regenerate new tissues simply by reversibly controlling cellular proliferation of matured cell types - after all the liver regenerates after partial hepatectomy by simple division of existing hepatocytes; and pancreatic $\beta$-cells proliferate to meet metabolic demand during pregnancy or partial pancreatectomy ${ }^{288}$. To this end, we have carried out a cell-based screen of murine pancreatic $\beta$-cells (reversibly immortalized with large- $T$ antigen to generate the large number of homogenous cells required for the screen) for molecules that reversibly proliferate $\beta$-cells and maintain their ability to produce insulin. We identified a number of known compounds including Wnt agonists and L-type calcium channel agonists, as well as novel compounds, which allow us to reversibly expand rodent $\beta$ cells (and more recently primary human islets), and are currently being tested in in vivo rodent models of Type I diabetes ${ }^{289}$. Others have demonstrated that the Wnt signaling agonist BIO also promote proliferation of cardiomyocytes ${ }^{290}$. Thus the controlled and reversible cellular proliferation of terminally differentiated cells which are normally quiescent and growth arrested (e.g., neurons, cardiomyocytes, hepatocytes, kidney epithelial cells, etc.) may possibly offer an ex vivo (or even in vivo) alternative to stem cells as a replacement for lost tissue, especially for tissues where no adult stem cells have yet been identified. Clearly the identification of molecules that control cell fate is providing new insights into the complex factors that regulate stem cell biology, but equally important, it may form the basis for a whole new therapeutic paradigm for synthetic molecules in medicine.

Another exciting opportunity for the academic community to exploit chemical libraries and screening technologies is in the area of orphan and neglected diseases. For example, there exists both a large research opportunity and a major unmet medical need with respect to molecules that kill persistent Mycobacterium tuberculosis (the biology of persistors is 
largely unknown) or liver stage Plasmodium falciparum, or molecules that target nonessential host factors that are required for viral replication (HIV, HCV, Dengue, etc.). In addition, there are a large number of orphan and neglected diseases (e.g., Type I diabetes, muscular dystrophies, spinal muscular atrophy, childhood cancers, Rett syndrome, Fragile $\mathrm{X}$, Huntington disease, etc.) for which no good treatments exist. The identification of molecules that modulate these disease processes may ultimately lead to new therapies, as well as provide new insights into the novel biology of many of these diseases, including epigenetic DNA modifications, alternative splicing, protein translocations, protein misfolding, and the like. Exciting examples include the identification of compounds by Stockwell and coworkers that selectively inhibit cell death in neuronal cells expressing the mutant huntingtin gene ${ }^{291,292}$; the isolation of molecules by the Dreyfuss laboratory that affect snRNP assembly by causing intramolecular disulfide crosslinks of $\mathrm{SMN}^{293}$; and the identification by Kelly and coworkers of molecules that modulate protein misfolding in transthyretin amyloidoses ${ }^{294}$. In our own lab, we have recently identified molecules that affect SMN2 splicing, $\gamma$-hemoglobin expression and the activity of translocated kinases in childhood cancers ${ }^{295}$.

Chemical libraries have many other exciting applications in chemistry, biology and medicine. They can be used to find molecules to explore the physiological effects of new biology - such as the roles of autophagy in neurodegenerative diseases ${ }^{296}$ or sirtuins in aging ${ }^{297}$. Chemical libraries have also been used in synthetic lethal screens, synergy screens to identify interacting pathways and regulatory mechanisms, and multicellular organism screens for developmental defects ${ }^{264}$ or effects on longevity ${ }^{298}$ (although the latter require relatively large amounts of compound). They have also afforded molecules that complement natural mutations, e.g., suppress nonsense mutations in dystrophin ${ }^{299}$ or partially restore the activity of a deletion mutation in the CFTR channel ${ }^{300}$. A similar approach can be applied to molecules that inhibit or activate engineered mutations in proteins ${ }^{301,302}$. It is also possible to design molecules that complement engineered mutations without the need for libraries. For example, in a beautiful series of experiments, Shokat and coworkers mutated kinase active sites to introduce "holes" (e.g., Thr338Gly in Src kinase) that allow them to bind synthetic inhibitors and substrates containing "bumps" (side chains) not recognized by wildtype kinases ${ }^{33}$ (Figure 17). This strategy in which one combines a genetic mutation with a synthetic mutation allows one to selectively inhibit the function of one member of a structurally homologous family of kinases to determine its cellular function, and thereby avoid the arduous task of synthesizing and assaying highly selective kinase inhibitors. A similar approach has been applied to natural mutations in nuclear receptors or enzymes ${ }^{303}$ and can likely be applied to other enzymes and receptors, such as lipid kinases and methyltransferases. A number of laboratories including those of Liu and Harbury have created libraries of small molecules by templated organic synthesis in which a DNA template is used to direct the stepwise synthesis of molecules using duplex formation to create high effective molarities of reactants ${ }^{28,29,304,305}$ (Figure 18). This approach is being used to search for selective ligands to biological receptors, as well as identify novel chemical reactions, and may one day lead to synthetic libraries which can be encoded, amplified, chemically mutated and selected in a process that mimics natural protein evolution. Diversity-based approaches are also being applied to the synthesis of libraries of larger 
biomolecules $^{306-313}$. For example, sequence-defined libraries of oligonucleotide, polypeptide and peptoid probes are being chemically fabricated on chips or beads (in some cases using a combination of solid phase synthesis and photolithographic methods) and used to interrogate mRNA expression on a genome wide level and identify single nucleotide polymorphisms in genetic studies ${ }^{310}$, or identify selective modulators of cell surface receptors ${ }^{311}$. Finally, the use of modern mass spectrometric and separation tools together with highly sensitive phenotypic or reporter-based cellular screens opens the opportunity to reexamine the library of natural small molecule metabolites derived from mammalian cells or the microbiome to identify molecules that affect cellular processes such as stem cell selfrenewal or differentiation, or bind and activate orphan receptors ${ }^{314,315}$ (including for example endogenous thyroid hormone derivatives with unusual activities ${ }^{316}$ ).

\section{Conclusion}

Chemistry continues to evolve from its historical focus on molecular structure, reactivity, and synthesis to take on the challenge of making small and large molecules, and even systems of molecules with tailored properties and functions. This requires improved theoretical and analytical tools, as well as innovative new synthetic strategies. Given the remarkable array of functional molecules found in living organisms, Mother Nature offers both inspiration and help in this regard through an approach to synthesis that seamlessly interfaces biology and chemistry. However, to fully exploit this opportunity, chemists must become highly proficient in the tools and concepts of modern biology without sacrificing their traditional deep understanding of molecular structure and reactivity. This represents a major challenge (and opportunity) for the traditional chemistry education - from secondary education through postdoctoral studies. It will require increased scientific partnerships between the disciplines of chemistry, biology and medicine in both education and research, and a reevaluation of the most important concepts and materials that we teach at the undergraduate and graduate levels. At the same time, we can inspire future generations of chemists with the exciting and highly relevant opportunities that exist at the interface of the chemical and biological sciences.

\section{Supplementary Material}

Refer to Web version on PubMed Central for supplementary material.

\section{Acknowledgments}

This work is supported by the National Institutes of Health, Department of Energy, Skaggs Institute for Chemical Biology, Juvenile Diabetes Research Foundation, California Institute for Regenerative Medicine, and Novartis Research Foundation. I would also like to thank the remarkable group of coworkers I have had the opportunity to work with over the years - who themselves are having a major impact on the direction of biological chemistry.

\section{References}

1. Lehn JM. Chem Soc Rev. 2007; 36:151-60. [PubMed: 17264919]

2. Breslow R, Dong SD. Chem Rev. 1998; 98:1997-2012. [PubMed: 11848956]

3. Venkateswara Rao P, Holm RH. Chem Rev. 2004; 104:527-59. [PubMed: 14871134]

4. Collman JP, Boulatov R, Sunderland CJ, Fu L. Chem Rev. 2004; 104:561-88. [PubMed: 14871135] 
5. Schultz PG, Dervan PB. J Am Chem Soc. 1983; 105:7748-7750.

6. White S, Szewczyk JW, Turner JM, Baird EE, Dervan PB. Nature. 1998; 391:468-71. [PubMed: 9461213]

7. Geierstanger BH, Mrksich M, Dervan PB, Wemmer DE. Science. 1994; 266:646-50. [PubMed: 7939719]

8. Benner SA, Sismour AM. Nat Rev Genet. 2005; 6:533-43. [PubMed: 15995697]

9. Kaiser ET. Ann NY Acad Sci. 1987; 501:14-20. [PubMed: 3475008]

10. Erlanger BF. Annu Rev Biochem. 1976; 45:257-83. [PubMed: 822780]

11. Gray HB. Chem Soc Rev. 1986; 15:17-30.

12. Orgel LE. Acc Chem Res. 1995; 28:109-18. [PubMed: 11542502]

13. Xie J, Schultz PG. Nat Rev Mol Cell Biol. 2006; 7:775-82. [PubMed: 16926858]

14. Cornish VW, Mendel D, Schultz PG. Angew Chem Int Engl Ed. 1995; 34:621-633.

15. Dougherty DA. Curr Opin Chem Biol. 2000; 4:645-52. [PubMed: 11102869]

16. Link AJ, Mock ML, Tirrell DA. Curr Opin Biotechnol. 2003; 14:603-9. [PubMed: 14662389]

17. Kool ET. Acc Chem Res. 2002; 35:936-43. [PubMed: 12437318]

18. Seo YJ, Hwang GT, Ordoukhanian P, Romesberg FE. J Am Chem Soc. 2009; 131:3246-52. [PubMed: 19256568]

19. Tae EL, Wu Y, Xia G, Schultz PG, Romesberg FE. J Am Chem Soc. 2001; 123:7439-40. [PubMed: 11472182]

20. Benner SA. Science. 2004; 306:625-6. [PubMed: 15499002]

21. Liu DR, Schultz PG. Angew Chem Int Ed Engl. 1999; 38:36-54.

22. Schultz PG, Lerner RA. Science. 1995; 269:1835-42. [PubMed: 7569920]

23. Smith GP, Petrenko VA. Chem Rev. 1997; 97:391-410. [PubMed: 11848876]

24. Bunin BA, Ellman JA. J Am Chem Soc. 1992; 114:10997-10998.

25. Gallop MA, Barrett RW, Dower WJ, Fodor SP, Gordon EM. J Med Chem. 1994; 37:1233-51. [PubMed: 8176700]

26. Alivisatos AP, Johnsson KP, Peng X, Wilson TE, Loweth CJ, Bruchez MP Jr, Schultz PG. Nature. 1996; 382:609-11. [PubMed: 8757130]

27. Rosi NL, Mirkin CA. Chem Rev. 2005; 105:1547-62. [PubMed: 15826019]

28. Gartner ZJ, Tse BN, Grubina R, Doyon JB, Snyder TM, Liu DR. Science. 2004; 305:1601-5. [PubMed: 15319493]

29. Wrenn SJ, Weisinger RM, Halpin DR, Harbury PB. J Am Chem Soc. 2007; 129:13137-43. [PubMed: 17918937]

30. Feinberg AW, Feigel A, Shevkoplyas SS, Sheehy S, Whitesides GM, Parker KK. Science. 2007; 317:1366-70. [PubMed: 17823347]

31. Hanson S, Best M, Bryan MC, Wong CH. Trends Biochem Sci. 2004; 29:656-63. [PubMed: 15544952]

32. Wong, CH., Whitesides, GM. Enzymes in Synthetic Organic Chemistry. Academic Press; 1994.

33. Bishop AC, Ubersax JA, Petsch DT, Matheos DP, Gray NS, Blethrow J, Shimizu E, Tsien JZ, Schultz PG, Rose MD, Wood JL, Morgan DO, Shokat KM. Nature. 2000; 407:395-401. [PubMed: 11014197]

34. Khosla C, Harbury PB. Nature. 2001; 409:247-52. [PubMed: 11196653]

35. Khosla C, Gokhale RS, Jacobsen JR, Cane DE. Annu Rev Biochem. 1999; 68:219-53. [PubMed: 10872449]

36. Kalaitzis JA, Izumikawa M, Xiang L, Hertweck C, Moore BS. J Am Chem Soc. 2003; 125:9290-1. [PubMed: 12889947]

37. Walsh CT. Science. 2004; 303:1805-10. [PubMed: 15031493]

38. Fischbach MA, Lai JR, Roche ED, Walsh CT, Liu DR. Proc Natl Acad Sci USA. 2007; 104:11951-6. [PubMed: 17620609]

39. Cane DE, Walsh CT, Khosla C. Science. 1998; 282:63-8. [PubMed: 9756477]

40. Walsh CT. Acc Chem Res. 2008; 41:4-10. [PubMed: 17506516] 
41. Blanchard S, Thorson JS. Curr Opin Chem Biol. 2006; 10:263-71. [PubMed: 16675288]

42. Thibodeaux CJ, Melancon CE 3rd, Liu HW. Angew Chem Int Ed Engl. 2008; 47:9814-59. [PubMed: 19058170]

43. Atsumi S, Hanai T, Liao JC. Nature. 2008; 451:86-9. [PubMed: 18172501]

44. Stephanopoulos G. Science. 2007; 315:801-4. [PubMed: 17289987]

45. Summerton J, Weller D. Antisense Nucleic Acid Drug Dev. 1997; 7:187-95. [PubMed: 9212909]

46. Nielsen PE. Mol Biotechnol. 2004; 26:233-48. [PubMed: 15004293]

47. Eschenmoser A. Science. 1999; 284:2118-24. [PubMed: 10381870]

48. Harbury PB, Zhang T, Kim PS, Alber T. Science. 1993; 262:1401-7. [PubMed: 8248779]

49. Hodges RS, Saund AK, Chong PC, St-Pierre SA, Reid RE. J Biol Chem. 1981; 256:1214-24. [PubMed: 7451500]

50. Regan L, DeGrado WF. Science. 1988; 241:976-8. [PubMed: 3043666]

51. Wade H, Stayrook SE, Degrado WF. Angew Chem Int Ed Engl. 2006; 45:4951-4. [PubMed: 16819737]

52. Cheng RP, Gellman SH, DeGrado WF. Chem Rev. 2001; 101:3219-32. [PubMed: 11710070]

53. Kirshenbaum K, Zuckermann RN, Dill KA. Curr Opin Struct Biol. 1999; 9:530-5. [PubMed: 10449369]

54. Petersson EJ, Craig CJ, Daniels DS, Qiu JX, Schepartz A. J Am Chem Soc. 2007; 129:5344-5. [PubMed: 17425318]

55. Seebach D, Beck AK, Bierbaum DJ. Chem Biodivers. 2004; 1:1111-239. [PubMed: 17191902]

56. Merrifield RB. J Am Chem Soc. 1963; 85:2149-2154.

57. Khorana HG. Science. 1979; 203:614-25. [PubMed: 366749]

58. Caruthers, MH. Synthesis and Applications of DNA and RNA. Narang, SA., editor. Academic Press; Orlando, FL: 1987. p. 47-94.

59. Prescher JA, Bertozzi CR. Cell. 2006; 126:851-4. [PubMed: 16959565]

60. Khidekel N, Ficarro SB, Peters EC, Hsieh-Wilson LC. Proc Natl Acad Sci USA. 2004; 101:131327. [PubMed: 15340146]

61. Keppler A, Gendreizig S, Gronemeyer T, Pick H, Vogel H, Johnsson K. Nat Biotechnol. 2003; 21:86-9. [PubMed: 12469133]

62. Yin J, Lin AJ, Buckett PD, Wessling-Resnick M, Golan DE, Walsh CT. Chem Biol. 2005; 12:999_ 1006. [PubMed: 16183024]

63. Fernandez-Suarez M, Baruah H, Martinez-Hernandez L, Xie KT, Baskin JM, Bertozzi CR, Ting AY. Nat Biotechnol. 2007; 25:1483-7. [PubMed: 18059260]

64. Flavell RR, Muir TW. Acc Chem Res. 2009; 42:107-16. [PubMed: 18939858]

65. Bain JD, Diala ES, Glabe CG, Dix TA, Chamberlin AR. J Am Chem Soc. 1989; 111:8013-8014.

66. Heckler TG, Chang LH, Zama Y, Naka T, Hecht SM. Tetrahedron. 1984; 40:87-94.

67. Murakami H, Ohta A, Ashigai H, Suga H. Nat Methods. 2006; 3:357-9. [PubMed: 16628205]

68. Lummis SC, Beene DL, Lee LW, Lester HA, Broadhurst RW, Dougherty DA. Nature. 2005; 438:248-52. [PubMed: 16281040]

69. Koh JT, Cornish VW, Schultz PG. Biochemistry. 1997; 36:11314-22. [PubMed: 9298950]

70. Thorson JS, Chapman E, Murphy EC, Schultz PG, Judice JK. J Am Chem Soc. 1995; 117:11571158.

71. Dedkova LM, Fahmi NE, Golovine SY, Hecht SM. J Am Chem Soc. 2003; 125:6616-7. [PubMed: 12769555]

72. Malkowski MG, Quartley E, Friedman AE, Babulski J, Kon Y, Wolfley J, Said M, Luft JR, Phizicky EM, DeTitta GT, Grayhack EJ. Proc Natl Acad Sci USA. 2007; 104:6678-83. [PubMed: 17426150]

73. Bentin T, Hamzavi R, Salomonsson J, Roy H, Ibba M, Nielsen PE. J Biol Chem. 2004; 279:1983945. [PubMed: 15004015]

74. Suchanek M, Radzikowska A, Thiele C. Nat Methods. 2005; 2:261-7. [PubMed: 15782218]

75. Furter R. Protein Sci. 1998; 7:419-26. [PubMed: 9521119]

J Am Chem Soc. Author manuscript; available in PMC 2018 March 12. 
76. Hendrickson WA, Ogata CM. Methods Enzymol. 1997; 276:494-523. [PubMed: 27799111]

77. Strable E, Prasuhn DE Jr, Udit AK, Brown S, Link AJ, Ngo JT, Lander G, Quispe J, Potter CS, Carragher B, Tirrell DA, Finn MG. Bioconjug Chem. 2008; 19:866-75. [PubMed: 18318461]

78. Carrico IS, Maskarinec SA, Heilshorn SC, Mock ML, Liu JC, Nowatzki PJ, Franck C, Ravichandran G, Tirrell DA. J Am Chem Soc. 2007; 129:4874-5. [PubMed: 17397163]

79. Beatty KE, Xie F, Wang Q, Tirrell DA. J Am Chem Soc. 2005; 127:14150-1. [PubMed: 16218586]

80. Steitz TA. Nat Rev Mol Cell Biol. 2008; 9:242-53. [PubMed: 18292779]

81. Yonath A. Mol Cell. 2005; 20:1-16.

82. Fechter P, Rudinger-Thirion J, Tukalo M, Giege R. Eur J Biochem. 2001; 268:761-7. [PubMed: 11168416]

83. Giege R, Sissler M, Florentz C. Nucleic Acids Res. 1998; 26:5017-35. [PubMed: 9801296]

84. Wang L, Schultz PG. Chem Biol. 2001; 8:883-90. [PubMed: 11564556]

85. Nozawa K, O’Donoghue P, Gundllapalli S, Araiso Y, Ishitani R, Umehara T, Soll D, Nureki O. Nature. 2009; 457:1163-7. [PubMed: 19118381]

86. Neumann H, Peak-Chew SY, Chin JW. Nat Chem Biol. 2008; 4:232-4. [PubMed: 18278036]

87. Yanagisawa T, Ishii R, Fukunaga R, Kobayashi T, Sakamoto K, Yokoyama S. Chem Biol. 2008; 15:1187-97. [PubMed: 19022179]

88. Wang L, Brock A, Herberich B, Schultz PG. Science. 2001; 292:498-500. [PubMed: 11313494]

89. Anderson JC, Wu N, Santoro SW, Lakshman V, King DS, Schultz PG. Proc Natl Acad Sci USA. 2004; 101:7566-71. [PubMed: 15138302]

90. Chen PR, Groff D, Guo J, Ou W, Geierstanger BH, Schultz PG. Angew Chem Int Engl Ed. 2009; 48:4052-5.

91. Chin JW, Cropp TA, Anderson JC, Mukherji M, Zhang Z, Schultz PG. Science. 2003; 301:964-7. [PubMed: 12920298]

92. Mukai T, Kobayashi T, Hino N, Yanagisawa T, Sakamoto K, Yokoyama S. Biochem Biophys Res Commun. 2008; 371:818-22. [PubMed: 18471995]

93. Young TS, Ahmad I, Brock A, Schultz PG. Biochemistry. 2009; 48:2643-2653. [PubMed: 19265424]

94. Chen S, Schultz PG, Brock A. J Mol Biol. 2007; 371:112-22. [PubMed: 17560600]

95. Cropp TA, Anderson JC, Chin JW. Nat Protoc. 2007; 2:2590-600. [PubMed: 17948002]

96. Liu W, Brock A, Chen S, Schultz PG. Nat Methods. 2007; 4:239-44. [PubMed: 17322890]

97. Ryu YH, Schultz PG. Nat Methods. 2006; 3:263-265. [PubMed: 16554830]

98. Wang Q, Wang L. J Am Chem Soc. 2008; 130:6066-7. [PubMed: 18426210]

99. Wang W, Takimoto JK, Louie GV, Baiga TJ, Noel JP, Lee KF, Slesinger PA, Wang L. Nat Neurosci. 2007; 10:1063-72. [PubMed: 17603477]

100. Mehl RA, Anderson JC, Santoro SW, Wang L, Martin AB, King DS, Horn DM, Schultz PG. J Am Chem Soc. 2003; 125:935-9. [PubMed: 12537491]

101. Wang L, Xie J, Schultz PG. Annu Rev Biophys Biomol Struct. 2006; 35:225-49. [PubMed: 16689635]

102. Lee HS, Spraggon G, Schultz PG, Wang F. J Am Chem Soc. 2009; 131:2481-2483. [PubMed: 19193005]

103. Xie J, Wang L, Wu N, Brock A, Spraggon G, Schultz PG. Nat Biotechnol. 2004; 22:1297-301. [PubMed: 15378068]

104. Brustad E, Bushey ML, Brock A, Chittuluru J, Schultz PG. Bioorg Med Chem Lett. 2008; 18:6004-6. [PubMed: 18845434]

105. Wang L, Brock A, Schultz PG. J Am Chem Soc. 2002; 124:1836-7. [PubMed: 11866580]

106. Chin JW, Santoro SW, Martin AB, King DS, Wang L, Schultz PG. J Am Chem Soc. 2002; 124:9026-7. [PubMed: 12148987]

107. Chin JW, Martin AB, King DS, Wang L, Schultz PG. Proc Natl Acad Sci USA. 2002; 99:110204. [PubMed: 12154230]

108. Chin JW, Schultz PG. ChemBioChem. 2002; 3:1135-7. [PubMed: 12404640] 
109. Tippmann EM, Liu W, Summerer D, Mack AV, Schultz PG. Chembiochem. 2007; 8:2210-4. [PubMed: 18000916]

110. Lee, HS., Dimla, R., Schultz, PG. Bioorg Med Chem Lett. In Press

111. Zeng H, Xie J, Schultz PG. Bioorg Med Chem Lett. 2006; 16:5356-9. [PubMed: 16934461]

112. Brustad EM, Lemke EA, Schultz PG, Deniz AA. J Am Chem Soc. 2008; 130:17664-5. [PubMed: 19108697]

113. Brustad E, Bushey ML, Lee JW, Groff D, Liu W, Schultz PG. Angew Chem Int Ed Engl. 2008; 47:8220-3. [PubMed: 18816552]

114. Deiters A, Schultz PG. Bioorg Med Chem Lett. 2005; 15:1521-4. [PubMed: 15713420]

115. Guo J, Wang J, Lee JS, Schultz PG. Angew Chem Int Ed Engl. 2008; 47:6399-401. [PubMed: 18624319]

116. Tsao ML, Tian F, Schultz PG. Chembiochem. 2005; 6:2147-9. [PubMed: 16317766]

117. Wang J, Schiller SM, Schultz PG. Angew Chem Int Ed Engl. 2007; 46:6849-51. [PubMed: 17685371]

118. Alfonta L, Zhang Z, Uryu S, Loo JA, Schultz PG. J Am Chem Soc. 2003; 125:14662-3. [PubMed: 14640614]

119. Seyedsayamdost MR, Xie J, Chan CT, Schultz PG, Stubbe J. J Am Chem Soc. 2007; 129:1506071. [PubMed: 17990884]

120. Tippmann EM, Schultz PG. Tetrahedron. 2007; 63:6182-6184.

121. Bose M, Groff D, Xie J, Brustad E, Schultz PG. J Am Chem Soc. 2006; 128:388-9. [PubMed: 16402807]

122. Deiters A, Groff D, Ryu Y, Xie J, Schultz PG. Angew Chem Int Ed Engl. 2006; 45:2728-31. [PubMed: 16548032]

123. Lemke EA, Summerer D, Geierstanger BH, Brittain SM, Schultz PG. Nat Chem Biol. 2007; 3:769-72. [PubMed: 17965709]

124. Peters FB, Brock A, Wang J, Schultz PG. Chem Biol. 2009; 16:148-52. [PubMed: 19246005]

125. Wu N, Deiters A, Cropp TA, King D, Schultz PG. J Am Chem Soc. 2004; 126:14306-7. [PubMed: 15521721]

126. Xie J, Liu W, Schultz PG. Angew Chem Int Ed Engl. 2007; 46:9239-42. [PubMed: 17893898]

127. Ye S, Kohrer C, Huber T, Kazmi M, Sachdev P, Yan EC, Bhagat A, RajBhandary UL, Sakmar TP. J Biol Chem. 2008; 283:1525-33. [PubMed: 17993461]

128. Deiters A, Geierstanger BH, Schultz PG. Chembiochem. 2005; 6:55-8. [PubMed: 15549724]

129. Cellitti SE, et al. J Am Chem Soc. 2008; 130:9268-81. [PubMed: 18576636]

130. Groff D, Thielges MC, Cellitti SE, Schultz PG, Romesberg FE. Angew Chem Int Ed Engl. 2009; 48:3478-81. [PubMed: 19347910]

131. Schultz KC, Supekova L, Ryu Y, Xie J, Perera R, Schultz PG. J Am Chem Soc. 2006; 128:139845. [PubMed: 17061854]

132. Wang J, Xie J, Schultz PG. J Am Chem Soc. 2006; 128:8738-9. [PubMed: 16819861]

133. Tsao ML, Summerer D, Ryu Y, Schultz PG. J Am Chem Soc. 2006; 128:4572-3. [PubMed: 16594684]

134. Wang L, Xie J, Deniz AA, Schultz PG. J Org Chem. 2003; 68:174-6. [PubMed: 12515477]

135. Jackson JC, Hammill JT, Mehl RA. J Am Chem Soc. 2007; 129:1160-6. [PubMed: 17263397]

136. Guo J, Wang J, Anderson JC, Schultz PG. Angew Chem Int Ed Engl. 2008; 47:722-5. [PubMed: 18069708]

137. Xie J, Supekova L, Schultz PG. ACS Chem Biol. 2007; 2:474-8. [PubMed: 17622177]

138. Liu CC, Brustad E, Liu W, Schultz PG. J Am Chem Soc. 2007; 129:10648-9. [PubMed: 17685615]

139. Turner JM, Graziano J, Spraggon G, Schultz PG. Proc Natl Acad Sci USA. 2006; 103:6483-8. [PubMed: 16618920]

140. Zhang Y, Wang L, Schultz PG, Wilson IA. Protein Sci. 2005; 14:1340-9. [PubMed: 15840835]

141. Deiters A, Cropp TA, Summerer D, Mukherji M, Schultz PG. Bioorg Med Chem Lett. 2004; 14:5743-5. [PubMed: 15501033] 
142. DeSantis G, Jones JB. Curr Opin Biotechnol. 1999; 10:324-30. [PubMed: 10449313]

143. Grünewald J, Hunt GS, Dong L, Niessen F, Wen BG, Tsao ML, Perera R, Kang M, Laffitte BA, Azarian S, Ruf W, Nasoff M, Lerner RA, Schultz PG, Smider VV. Proc Natl Acad Sci USA. 2009; 106:4337-42. [PubMed: 19246393]

144. Doyle HA, Mamula MJ. Trends Immunol. 2001; 22:443-9. [PubMed: 11473834]

145. Neumann H, Hazen JL, Weinstein J, Mehl RA, Chin JW. J Am Chem Soc. 2008; 130:4028-33. [PubMed: 18321101]

146. Summerer D, Chen S, Wu N, Deiters A, Chin JW, Schultz PG. Proc Natl Acad Sci USA. 2006; 103:9785-9. [PubMed: 16785423]

147. Lee HS, Guo J, Lemke E, Dimla R, Schultz PG. Science. Submitted.

148. Lee HS, Schultz PG. J Am Chem Soc. 2008; 130:13194-5. [PubMed: 18788806]

149. Chen HT, Warfield L, Hahn S. Nat Struct Mol Biol. 2007; 14:696-703. [PubMed: 17632521]

150. Hino N, Hayashi A, Sakamoto K, Yokoyama S. Nat Protoc. 2006; 1:2957-62. [PubMed: 17406555]

151. Weibezahn J, Tessarz P, Schlieker C, Zahn R, Maglica Z, Lee S, Zentgraf H, Weber-Ban EU, Dougan DA, Tsai FT, Mogk A, Bukau B. Cell. 2004; 119:653-65. [PubMed: 15550247]

152. Liu CC, Mack AV, Tsao ML, Mills JH, Lee HS, Choe H, Farzan M, Schultz PG, Smider VV. Proc Natl Acad Sci USA. 2008; 105:17688-93. [PubMed: 19004806]

153. Liu, CC., Mack, AV., Brustad, EM., Mills, JH., Groff, D., Smider, VV., Schultz, PG. J Am Chem Soc. In press

154. Rackham O, Chin JW. Nat Chem Biol. 2005; 1:159-66. [PubMed: 16408021]

155. Burnet, FM. The Clonal Selection Theory of Acquired Immunity. Vanderbilt University Press; Nashville, TN: 1959.

156. Pollack SJ, Jacobs JW, Schultz PG. Science. 1986; 234:1570-3. [PubMed: 3787262]

157. Tramontano A, Janda KD, Lerner RA. Science. 1986; 234:1566-70. [PubMed: 3787261]

158. Schultz PG, Lerner RA. Nature. 2002; 418:485. [PubMed: 12152057]

159. Schultz PG, Yin J, Lerner RA. Angew Chem Int Ed Engl. 2002; 41:4427-37. [PubMed: 12458503]

160. Pauling L. Nature. 1948; 161:707-9. [PubMed: 18860270]

161. Jacobsen JR, Prudent JR, Kochersperger L, Yonkovich S, Schultz PG. Science. 1992; 256:365-7. [PubMed: 1566082]

162. Hilvert D, Carpenter SH, Nared KD, Auditor MT. Proc Natl Acad Sci USA. 1988; 85:4953-5. [PubMed: 3393525]

163. Barbas CF III, Heine A, Zhong G, Hoffmann T, Gramatikova S, Bjornestedt R, List B, Anderson J, Stura EA, Wilson IA, Lerner RA. Science. 1997; 278:2085-92. [PubMed: 9405338]

164. List B, Lerner RA, Barbas CF III. J Am Chem Soc. 2000; 122:2395-2396.

165. Lelais G, MacMillan DWC. Aldrichimica Acta. 2006; 39:79-87.

166. Schultz PG, Lerner RA. Acc Chem Res. 1993; 26:391-395.

167. Cochran AG, Schultz PG. Science. 1990; 249:781-3. [PubMed: 2389144]

168. Yin J, Andryski SE, Beuscher AE, Stevens RC, Schultz PG. Proc Natl Acad Sci USA. 2003; 100:856-61. [PubMed: 12552112]

169. Patten PA, Gray NS, Yang PL, Marks CB, Wedemayer GJ, Boniface JJ, Stevens RC, Schultz PG. Science. 1996; 271:1086-91. [PubMed: 8599084]

170. Yin J, Beuscher AEt, Andryski SE, Stevens RC, Schultz PG. J Mol Biol. 2003; 330:651-6. [PubMed: 12850137]

171. Zimmermann J, Oakman EL, Thorpe IF, Shi X, Abbyad P, Brooks CL 3rd, Boxer SG, Romesberg FE. Proc Natl Acad Sci US. 2006; 103:13722-7.

172. Pauling L. J Am Chem Soc. 1940; 62:2643.

173. Foote J, Milstein C. Proc Natl Acad Sci USA. 1994; 91:10370-4. [PubMed: 7937957]

174. Benkovic SJ, Hammes-Schiffer S. Science. 2003; 301:1196-202. [PubMed: 12947189] 
175. Wrighton NC, Farrell FX, Chang R, Kashyap AK, Barbone FP, Mulcahy LS, Johnson DL, Barrett RW, Jolliffe LK, Dower WJ. Science. 1996; 273:458-64. [PubMed: 8662529]

176. Choo Y, Sanchez-Garcia I, Klug A. Nature. 1994; 372:642-5. [PubMed: 7990954]

177. Greisman HA, Pabo CO. Science. 1997; 275:657-61. [PubMed: 9005850]

178. Wu H, Yang WP, Barbas CF 3rd. Proc Natl Acad Sci USA. 1995; 92:344-8. [PubMed: 7831288]

179. Dickerson MB, Sandhage KH, Naik RR. Chem Rev. 2008; 108:4935-78. [PubMed: 18973389]

180. Whaley SR, English DS, Hu EL, Barbara PF, Belcher AM. Nature. 2000; 405:665-8. [PubMed: 10864319]

181. Liang R, Yan L, Loebach J, Ge M, Uozumi Y, Sekanina K, Horan N, Gildersleeve J, Thompson C, Smith A, Biswas K, Still WC, Kahne D. Science. 1996; 274:1520-2. [PubMed: 8929411]

182. Ellington AD, Szostak JW. Nature. 1990; 346:818-22. [PubMed: 1697402]

183. Tuerk C, Gold L. Science. 1990; 249:505-10. [PubMed: 2200121]

184. Wilson DS, Szostak JW. Annu Rev Biochem. 1999; 68:611-47. [PubMed: 10872462]

185. Joyce GF. Annu Rev Biochem. 2004; 73:791-836. [PubMed: 15189159]

186. Unrau PJ, Bartel DP. Nature. 1998; 395:260-3. [PubMed: 9751052]

187. Mandal M, Breaker RR. Nat Rev Mol Cell Biol. 2004; 5:451-63. [PubMed: 15173824]

188. Hager AJ, Pollard JD, Szostak JW. Chem Biol. 1996; 3:717-25. [PubMed: 8939686]

189. Johnston WK, Unrau PJ, Lawrence MS, Glasner ME, Bartel DP. Science. 2001; 292:1319-25. [PubMed: 11358999]

190. Lincoln TA, Joyce GF. Science. 2009; 323:1229-32. [PubMed: 19131595]

191. Stemmer WP. Nature. 1994; 370:389-91. [PubMed: 8047147]

192. Wang L, Jackson WC, Steinbach PA, Tsien RY. Proc Natl Acad Sci USA. 2004; 101:16745-9. [PubMed: 15556995]

193. Davidson AR, Sauer RT. Proc Natl Acad Sci USA. 1994; 91:2146-50. [PubMed: 8134363]

194. Graziano JJ, Liu W, Perera R, Geierstanger BH, Lesley SA, Schultz PG. J Am Chem Soc. 2008; 130:176-85. [PubMed: 18067292]

195. Kamtekar S, Schiffer JM, Xiong H, Babik JM, Hecht MH. Science. 1993; 262:1680-5. [PubMed: 8259512]

196. Keefe AD, Szostak JW. Nature. 2001; 410:715-8. [PubMed: 11287961]

197. You L, Cox RS 3rd, Weiss R, Arnold FH. Nature. 2004; 428:868-71. [PubMed: 15064770]

198. Levskaya A, Chevalier AA, Tabor JJ, Simpson ZB, Lavery LA, Levy M, Davidson EA, Scouras A, Ellington AD, Marcotte EM, Voigt CA. Nature. 2005; 438:441-2. [PubMed: 16306980]

199. Gallagher, SS., Cornish, VW. Encyclopedia for Chemical Biology. Wiley-VCH Verlag GmbH \& Co; Germany: 2008.

200. Brooks H, Lebleu B, Vives E. Adv Drug Deliv Rev. 2005; 57:559-77. [PubMed: 15722164]

201. Murphy JE, Uno T, Hamer JD, Cohen FE, Dwarki V, Zuckermann RN. Proc Natl Acad Sci USA. 1998; 95:1517-22. [PubMed: 9465047]

202. Wender PA, Mitchell DJ, Pattabiraman K, Pelkey ET, Steinman L, Rothbard JB. Proc Natl Acad Sci USA. 2000; 97:13003-8. [PubMed: 11087855]

203. Xiang XD, Sun X, Briceno G, Lou Y, Wang KA, Chang H, Wallace-Freedman WG, Chen SW, Schultz PG. Science. 1995; 268:1738-1740. [PubMed: 17834993]

204. Briceño G, Chang H, Sun X, Schultz PG, Xiang XD. Science. 1995; 270:273-275.

205. Wang J, Yoo Y, Gao C, Takeuchi II, Sun X, Chang H, Xiang X, Schultz PG. Science. 1998; 279:1712-4. [PubMed: 9497288]

206. Danielson E, Devenney M, Giaquinta DM, Golden JH, Haushalter RC, McFarland EW, Poojary DM, Reaves CM, Weinberg WH, Wu XD. Science. 1998; 279:837-9. [PubMed: 9452377]

207. Arriola DJ, Carnahan EM, Hustad PD, Kuhlman RL, Wenzel TT. Science. 2006; 312:714-9. [PubMed: 16675694]

208. Maier WF, Stowe K, Sieg S. Angew Chem Int Ed Engl. 2007; 46:6016-67. [PubMed: 17640024]

209. Turner HW, Volpe AF Jr, Weinberg WH. Surf Sci. 2009; 603:1763-1769.

210. Rajan K. Ann Rev Materials Res. 2008; 38:299-322. 
211. Xiang, XD., Takeuchi, I. Combinatorial Materials Synthesis. CRC Press; 2003.

212. Bailey, M., Kaye, S. Unpublished results.

213. Lesley SA, et al. Proc Natl Acad Sci USA. 2002; 99:11664-9. [PubMed: 12193646]

214. Jandeleit B, Schaefer DJ, Powers TS, Turner HW, Weinberg WH. Angew Chem Int Ed Engl. 1999; 38:2494-2532. [PubMed: 10508328]

215. Lewis, GJ., Sachtler, JWA., Low, JJ., Lesch, DA., Dosek, P., Faheem, S., Knight, LM., Halloran, L. DOE Hydrogen Program Peer Review. Washington, D.C: 2008.

216. Bonakdarpour A, Hewitt KC, Hatchard TD, Fleischauer MD, Dahn JR. Thin Solid Films. 2003; 440:11-18.

217. Danielson E, Golden JH, McFarland EW, Reaves CM, Weinberg WH, Di Wu X. Nature. 1997; 389:944-948.

218. Gordon EM, Barrett RW, Dower WJ, Fodor SP, Gallop MA. J Med Chem. 1994; 37:1385-401. [PubMed: 8182695]

219. Thompson LA, Ellman JA. Chem Rev. 1996; 96:555-600. [PubMed: 11848765]

220. Bloch K. Acc Chem Res. 1969; 2:193-202.

221. Tsien, RY. Calcium as a cellular regulator. Carafoli, E., Klee, C., editors. Oxford Univ. Press; New York: 1999. p. 28-54.

222. Bauer JH. Am J Hypertens. 1990; 3:331-7. [PubMed: 2189445]

223. Wong DT, Perry KW, Bymaster FP. Nat Rev Drug Discov. 2005; 4:764-74. [PubMed: 16121130]

224. Melnick JS, et al. Proc Natl Acad Sci USA. 2006; 103:3153-8. [PubMed: 16492761]

225. Goldstein DM, Gray NS, Zarrinkar PP. Nat Rev Drug Discov. 2008; 7:391-7. [PubMed: 18404149]

226. Hong J, Edel JB, deMello AJ. Drug Discov Today. 2009; 14:134-46. [PubMed: 18983933]

227. Plouffe D, et al. Proc Natl Acad Sci USA. 2008; 105:9059-64. [PubMed: 18579783]

228. Blackwell HE, Perez L, Stavenger RA, Tallarico JA, Cope Eatough E, Foley MA, Schreiber SL. Chem Biol. 2001; 8:1167-82. [PubMed: 11755396]

229. Clemons PA, Koehler AN, Wagner BK, Sprigings TG, Spring DR, King RW, Schreiber SL, Foley MA. Chem Biol. 2001; 8:1183-95. [PubMed: 11755397]

230. Arya P, Joseph R, Chou DT. Chem Biol. 2002; 9:145-56. [PubMed: 11880029]

231. Ding S, Gray NS, Wu X, Ding Q, Schultz PG. J Am Chem Soc. 2002; 124:1594-6. [PubMed: 11853431]

232. Bunin BA, Plunkett MJ, Ellman JA. Proc Natl Acad Sci USA. 1994; 91:4708-12. [PubMed: 8197123]

233. Stockwell BR. Nat Rev Genet. 2000; 1:116-25. [PubMed: 11253651]

234. Knight ZA, Shokat KM. Cell. 2007; 128:425-30. [PubMed: 17289560]

235. Schreiber SL. Science. 1991; 251:283-7. [PubMed: 1702904]

236. Chanda SK, et al. Proc Natl Acad Sci USA. 2003; 100:12153-8. [PubMed: 14514886]

237. Willingham AT, Orth AP, Batalov S, Peters EC, Wen BG, Aza-Blanc P, Hogenesch JB, Schultz PG. Science. 2005; 309:1570-3. [PubMed: 16141075]

238. Huang Q, Raya A, DeJesus P, Chao SH, Quon KC, Caldwell JS, Chanda SK, Izpisua-Belmonte JC, Schultz PG. Proc Natl Acad Sci USA. 2004; 101:3456-61. [PubMed: 14990790]

239. Ong SE, et al. Proc Natl Acad Sci USA. 2009; 106:4617-22. [PubMed: 19255428]

240. Bosch F, Rosich L. Pharmacology. 2008; 82:171-9. [PubMed: 18679046]

241. Hardman, JG., Limbird, LE., Gilman, AG. Goodman \& Gilman's The Pharmacological Basis of Therapeutics. 10th. McGraw-Hill; New York: p. 2001

242. Ding S, Schultz PG. Nat Biotechnol. 2004; 22:833-40. [PubMed: 15229546]

243. Ding S, Schultz PG. Curr Top Med Chem. 2005; 5:383-95. [PubMed: 15892681]

244. Fuchs E, Segre JA. Cell. 2000; 100:143-55. [PubMed: 10647939]

245. Weissman IL. Cell. 2000; 100:157-68. [PubMed: 10647940]

246. Murry CE, Keller G. Cell. 2008; 132:661-80. [PubMed: 18295582]

247. Yamanaka S. Cell Stem Cell. 2007; 1:39-49. [PubMed: 18371333] 
248. Zhou Q, Melton DA. Cell Stem Cell. 2008; 3:382-8. [PubMed: 18940730]

249. Xu Y, Shi Y, Ding S. Nature. 2008; 453:338-44. [PubMed: 18480815]

250. Boitano, A., Cooke, M., Schultz, PG. 50th ASH Annual Meeting and Exposition. San Francisco, CA: 2008.

251. Warashina M, Min KH, Kuwabara T, Huynh A, Gage FH, Schultz PG, Ding S. Angew Chem Int Ed Engl. 2006; 45:591-3. [PubMed: 16323231]

252. Wurdak, H., Zhu, S., Schultz, PG. unpublished results.

253. Wu X, Walker J, Zhang J, Ding S, Schultz PG. Chem Biol. 2004; 11:1229-38. [PubMed: 15380183]

254. Johnson, K., Schultz, PG. unpublished results.

255. Diamandis P, Wildenhain J, Clarke ID, Sacher AG, Graham J, Bellows DS, Ling EK, Ward RJ, Jamieson LG, Tyers M, Dirks PB. Nat Chem Biol. 2007; 3:268-73. [PubMed: 17417631]

256. Sadek H, Hannack B, Choe E, Wang J, Latif S, Garry MG, Garry DJ, Longgood J, Frantz DE, Olson EN, Hsieh J, Schneider JW. Proc Natl Acad Sci USA. 2008; 105:6063-8. [PubMed: 18420817]

257. Saxe JP, Wu H, Kelly TK, Phelps ME, Sun YE, Kornblum HI, Huang J. Chem Biol. 2007; 14:1019-30. [PubMed: 17884634]

258. Schneider JW, Gao Z, Li S, Farooqi M, Tang TS, Bezprozvanny I, Frantz DE, Hsieh J. Nat Chem Biol. 2008; 4:408-10. [PubMed: 18552832]

259. Buckbinder L, et al. Proc Natl Acad Sci USA. 2007; 104:10619-24. [PubMed: 17537919]

260. Hao J, Daleo MA, Murphy CK, Yu PB, Ho JN, Hu J, Peterson RT, Hatzopoulos AK, Hong CC. PLoS ONE. 2008; 3:e2904. [PubMed: 18682835]

261. Kawatani M, Okumura H, Honda K, Kanoh N, Muroi M, Dohmae N, Takami M, Kitagawa M, Futamura Y, Imoto M, Osada H. Proc Natl Acad Sci USA. 2008; 105:11691-6. [PubMed: 18695250]

262. Chen JK, Taipale J, Young KE, Maiti T, Beachy PA. Proc Natl Acad Sci USA. 2002; 99:14071-6. [PubMed: 12391318]

263. Stanton BZ, Peng LF, Maloof N, Nakai K, Wang X, Duffner JL, Taveras KM, Hyman JM, Lee SW, Koehler AN, Chen JK, Fox JL, Mandinova A, Schreiber SL. Nat Chem Biol. 2009; 5:154-6. [PubMed: 19151731]

264. Yu PB, Hong CC, Sachidanandan C, Babitt JL, Deng DY, Hoyng SA, Lin HY, Bloch KD, Peterson RT. Nat Chem Biol. 2008; 4:33-41. [PubMed: 18026094]

265. Lee J, Wu X, Pasca di Magliano M, Peters EC, Wang Y, Hong J, Hebrok M, Ding S, Cho CY, Schultz PG. ChemBioChem. 2007; 8:1916-9. [PubMed: 17886323]

266. Zhang Q, Major MB, Takanashi S, Camp ND, Nishiya N, Peters EC, Ginsberg MH, Jian X, Randazzo PA, Schultz PG, Moon RT, Ding S. Proc Natl Acad Sci USA. 2007; 104:7444-8. [PubMed: 17460038]

267. Visvader JE, Lindeman GJ. Nat Rev Cancer. 2008; 8:755-68. [PubMed: 18784658]

268. Dubrovska A, Kim S, Salamone RJ, Walker JR, Maira SM, Garcia-Echeverria C, Schultz PG, Reddy VA. Proc Natl Acad Sci USA. 2009; 106:268-73. [PubMed: 19116269]

269. Chen S, Do JT, Zhang Q, Yao S, Yan F, Peters EC, Scholer HR, Schultz PG, Ding S. Proc Natl Acad Sci USA. 2006; 103:17266-71. [PubMed: 17088537]

270. Wu X, Ding S, Ding Q, Gray NS, Schultz PG. J Am Chem Soc. 2004; 126:1590-1. [PubMed: 14871063]

271. Zhu S, Wurdak H, Wang J, Lyssiotis CA, Peters EC, Cho C, Wu X, Schultz PG. Cell Stem Cell. 2009; 4:416-26. [PubMed: 19427291]

272. Borowiak M, Maehr R, Chen S, Chen AE, Tang W, Fox JL, Schreiber SL, Melton DA. Cell Stem Cell. 2009; 4:348-58. [PubMed: 19341624]

273. Chen S, Borowiak M, Fox JL, Maehr R, Osafune K, Davidow L, Lam K, Peng LF, Schreiber SL, Rubin LL, Melton D. Nat Chem Biol. 2009; 5:258-65. [PubMed: 19287398]

274. Gonzales, R., Schultz, PG. Unpublished results.

275. Takahashi K, Yamanaka S. Cell. 2006; 126:663-76. [PubMed: 16904174] 
276. Takahashi K, Tanabe K, Ohnuki M, Narita M, Ichisaka T, Tomoda K, Yamanaka S. Cell. 2007; 131:861-72. [PubMed: 18035408]

277. Park IH, Zhao R, West JA, Yabuuchi A, Huo H, Ince TA, Lerou PH, Lensch MW, Daley GQ. Nature. 2008; 451:141-6. [PubMed: 18157115]

278. Kim JB, et al. Cell. 2009; 136:411-9. [PubMed: 19203577]

279. Wernig M, Meissner A, Foreman R, Brambrink T, Ku M, Hochedlinger K, Bernstein BE, Jaenisch R. Nature. 2007; 448:318-24. [PubMed: 17554336]

280. Chen S, Takanashi S, Zhang Q, Xiong W, Zhu S, Peters EC, Ding S, Schultz PG. Proc Natl Acad Sci USA. 2007; 104:10482-7. [PubMed: 17566101]

281. Chen S, Zhang Q, Wu X, Schultz PG, Ding S. J Am Chem Soc. 2004; 126:410-1. [PubMed: 14719906]

282. Lyssiotis CA, Walker J, Wu C, Kondo T, Schultz PG, Wu X. Proc Natl Acad Sci USA. 2007; 104:14982-7. [PubMed: 17855562]

283. Liu A, Han YR, Li J, Sun D, Ouyang M, Plummer MR, Casaccia-Bonnefil P. J Neurosci. 2007; 27:7339-43. [PubMed: 17611286]

284. Shi Y, Desponts C, Do JT, Hahm HS, Scholer HR, Ding S. Cell Stem Cell. 2008; 3:568-74. [PubMed: 18983970]

285. Huangfu D, Maehr R, Guo W, Eijkelenboom A, Snitow M, Chen AE, Melton DA. Nat Biotechnol. 2008; 26:795-7. [PubMed: 18568017]

286. Li W, Wei W, Zhu S, Zhu J, Shi Y, Lin T, Hao E, Hayek A, Deng H, Ding S. Cell Stem Cell. 2009; 4:16-9. [PubMed: 19097958]

287. Shi Y, Do JT, Desponts C, Hahm HS, Scholer HR, Ding S. Cell Stem Cell. 2008; 2:525-8. [PubMed: 18522845]

288. Zaret KS, Grompe M. Science. 2008; 322:1490-4. [PubMed: 19056973]

289. Wang W, Walker JR, Wang X, Tremblay MS, Lee JW, Wu X, Schultz PG. Proc Natl Acad Sci USA. 2009; 106:1427-32. [PubMed: 19164755]

290. Tseng AS, Engel FB, Keating MT. Chem Biol. 2006; 13:957-63. [PubMed: 16984885]

291. Bauer A, Stockwell B. Chem Rev. 2008; 108:1774-86. [PubMed: 18447397]

292. Varma H, Voisine C, DeMarco CT, Cattaneo E, Lo DC, Hart AC, Stockwell BR. Nat Chem Biol. 2007; 3:99-100. [PubMed: 17195849]

293. Wan L, Ottinger E, Cho S, Dreyfuss G. Mol Cell. 2008; 31:244-54. [PubMed: 18657506]

294. Johnson SM, Wiseman RL, Sekijima Y, Green NS, Adamski-Werner SL, Kelly JW. Acc Chem Res. 2005; 38:911-21. [PubMed: 16359163]

295. Galkin AV, et al. Proc Natl Acad Sci USA. 2007; 104:270-5. [PubMed: 17185414]

296. Sarkar S, Perlstein EO, Imarisio S, Pineau S, Cordenier A, Maglathlin RL, Webster JA, Lewis TA, O'Kane CJ, Schreiber SL, Rubinsztein DC. Nat Chem Biol. 2007; 3:331-8. [PubMed: 17486044]

297. Howitz KT, Bitterman KJ, Cohen HY, Lamming DW, Lavu S, Wood JG, Zipkin RE, Chung P, Kisielewski A, Zhang LL, Scherer B, Sinclair DA. Nature. 2003; 425:191-6. [PubMed: 12939617]

298. Petrascheck M, Ye X, Buck LB. Nature. 2007; 450:553-6. [PubMed: 18033297]

299. Welch EM, et al. Nature. 2007; 447:87-91. [PubMed: 17450125]

300. Pedemonte N, Lukacs GL, Du K, Caci E, Zegarra-Moran O, Galietta LJ, Verkman AS. J Clin Invest. 2005; 115:2564-71. [PubMed: 16127463]

301. Guo Z, Zhou D, Schultz PG. Science. 2000; 288:2042-5. [PubMed: 10856217]

302. Lin Q, Barbas CF, Schultz PG 3rd. J Am Chem Soc. 2003; 125:612-3. [PubMed: 12526643]

303. Hassan AQ, Koh JT. J Am Chem Soc. 2006; 128:8868-74. [PubMed: 16819881]

304. Gartner ZJ, Liu DR. J Am Chem Soc. 2001; 123:6961-3. [PubMed: 11448217]

305. Halpin DR, Harbury PB. PLoS Biol. 2004; 2:E174. [PubMed: 15221028]

306. Geysen HM, Mason TJ. Bioorg Med Chem Lett. 1993; 3:397-404.

307. Lam KS, Hruby VJ, Lebl M, Knapp RJ, Kazmierski WM, Hersh EM, Salmon SE. Bioorg Med Chem Lett. 1993; 3:419-424. 
308. Houghten RA, Pinilla C, Blondelle SE, Appel JR, Dooley CT, Cuervo JH. Nature. 1991; 354:846. [PubMed: 1719428]

309. Ohlmeyer MH, Swanson RN, Dillard LW, Reader JC, Asouline G, Kobayashi R, Wigler M, Still WC. Proc Natl Acad Sci USA. 1993; 90:10922-6. [PubMed: 7504286]

310. Chee M, Yang R, Hubbell E, Berno A, Huang XC, Stern D, Winkler J, Lockhart DJ, Morris MS, Fodor SP. Science. 1996; 274:610-4. [PubMed: 8849452]

311. Udugamasooriya DG, Dineen SP, Brekken RA, Kodadek T. J Am Chem Soc. 2008; 130:5744-52. [PubMed: 18386897]

312. Winssinger N, Harris JL, Backes BJ, Schultz PG. Angew Chem Int Ed Engl. 2001; 40:31523155.

313. Choe Y, Leonetti F, Greenbaum DC, Lecaille F, Bogyo M, Bromme D, Ellman JA, Craik CS. J Biol Chem. 2006; 281:12824-32. [PubMed: 16520377]

314. Backhed F, Ley RE, Sonnenburg JL, Peterson DA, Gordon JI. Science. 2005; 307:1915-20. [PubMed: 15790844]

315. Wikoff WR, Anfora AT, Liu J, Schultz PG, Lesley SA, Peters EC, Siuzdak G. Proc Natl Acad Sci USA. 2009; 106:3698-703. [PubMed: 19234110]

316. Scanlan TS. Endocrinology. 2009; 150:1108-11. [PubMed: 19116337] 


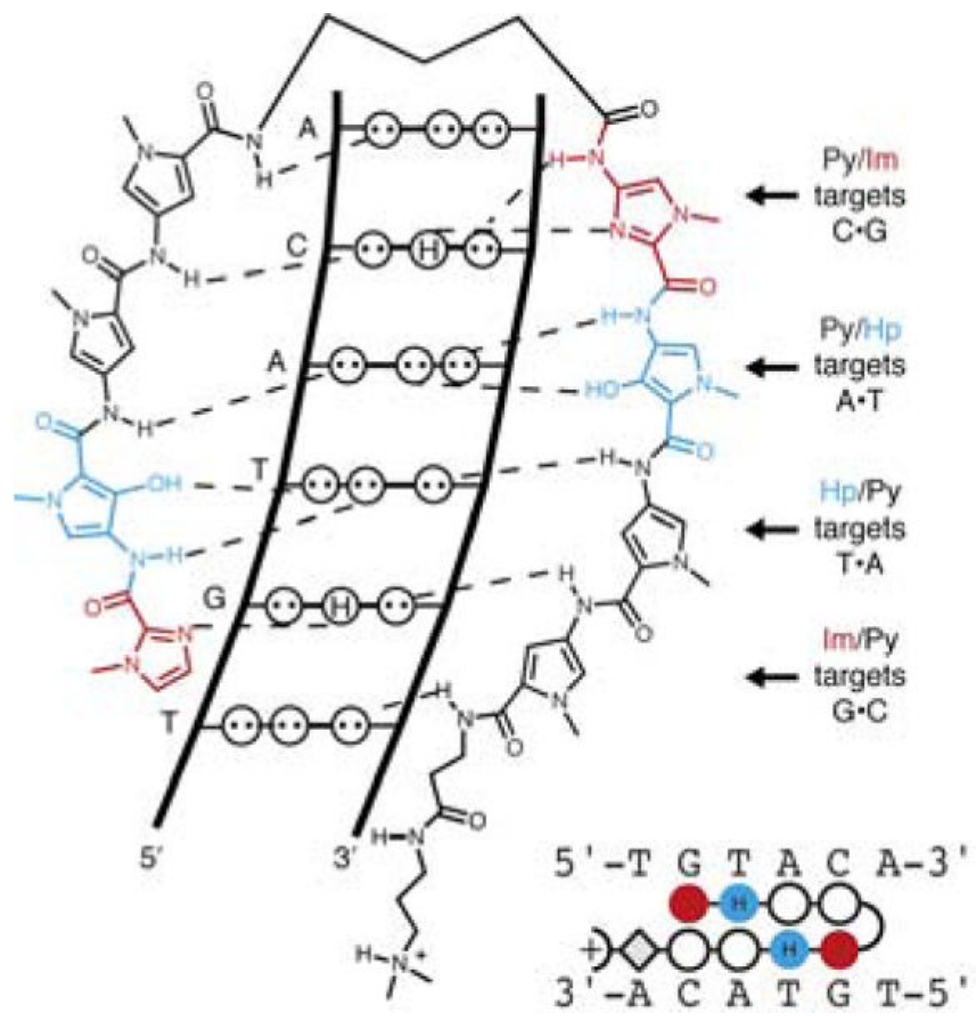

Figure 1.

Synthetic molecules that sequence specifically bind duplex DNA based on specific hydrogen bonding interactions, much like transcriptional repressors ${ }^{6}$ (Courtesy of Peter Dervan). 

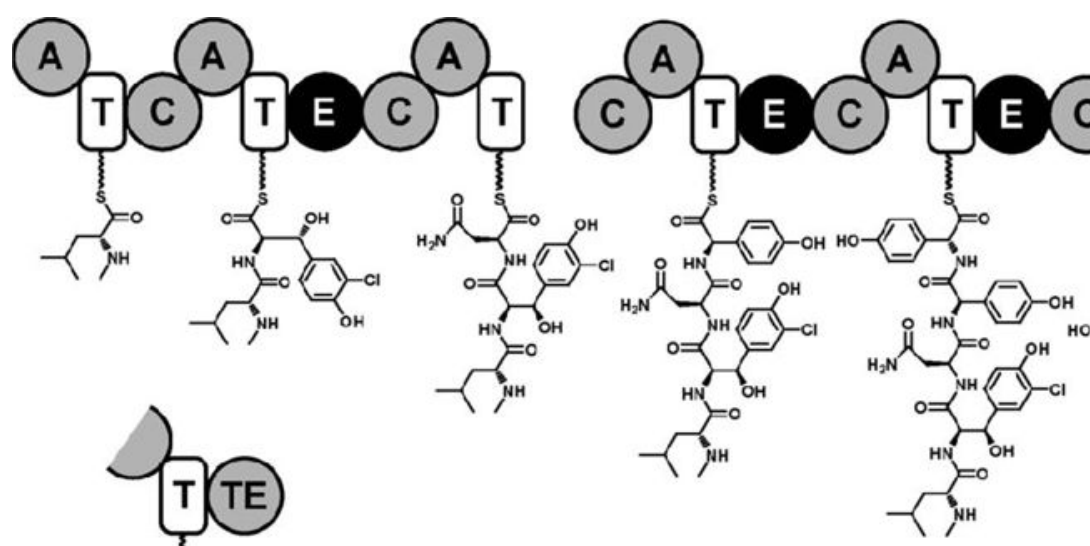

(A)
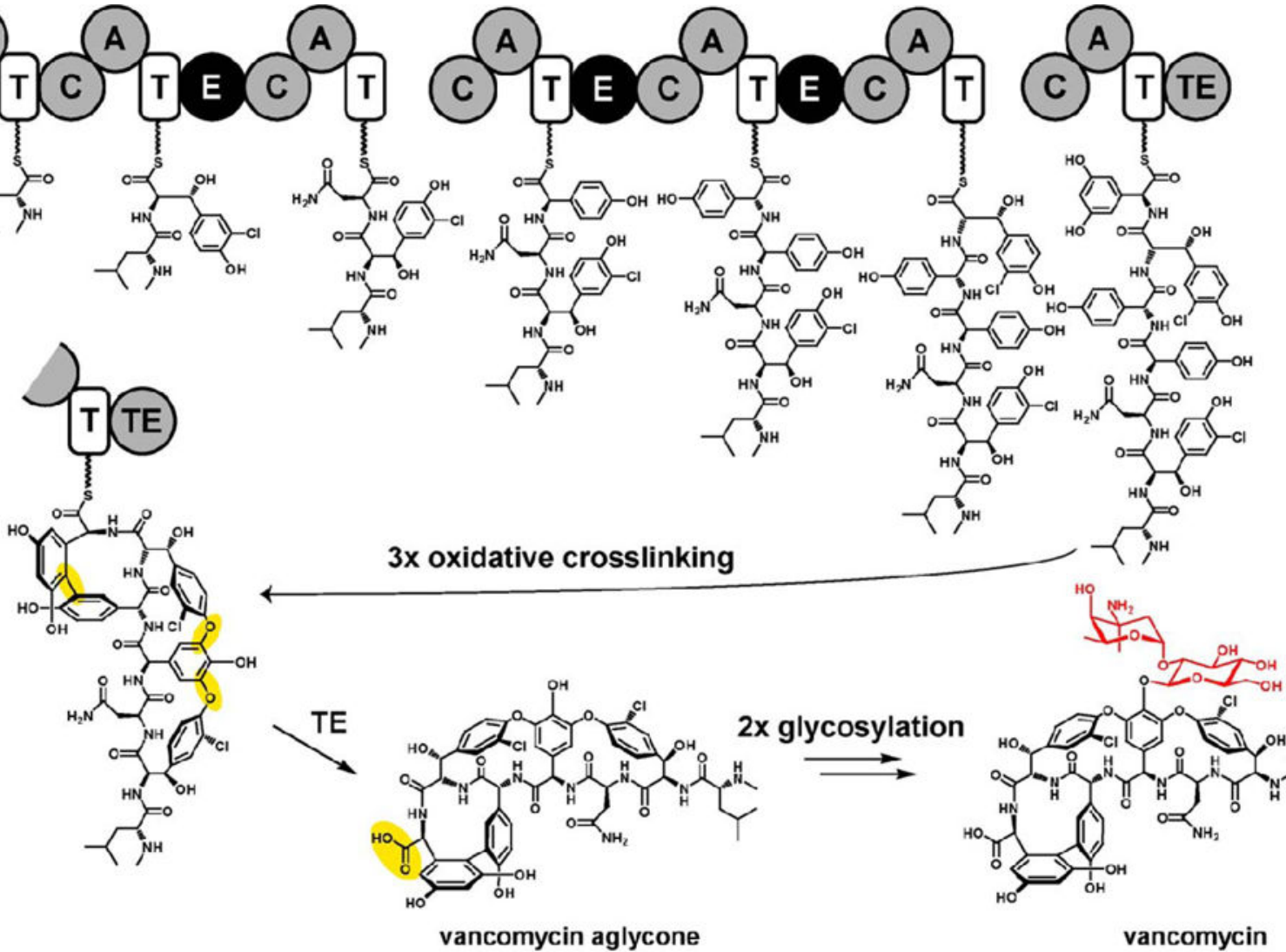

glycosylation

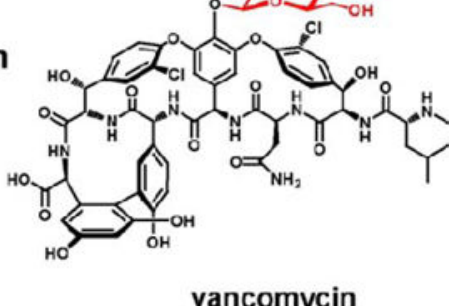

Figure 2.

Modular thiotemplated assembly lines for the biosynthesis of vancomycin ${ }^{37}$ (Courtesy Christopher Walsh). 


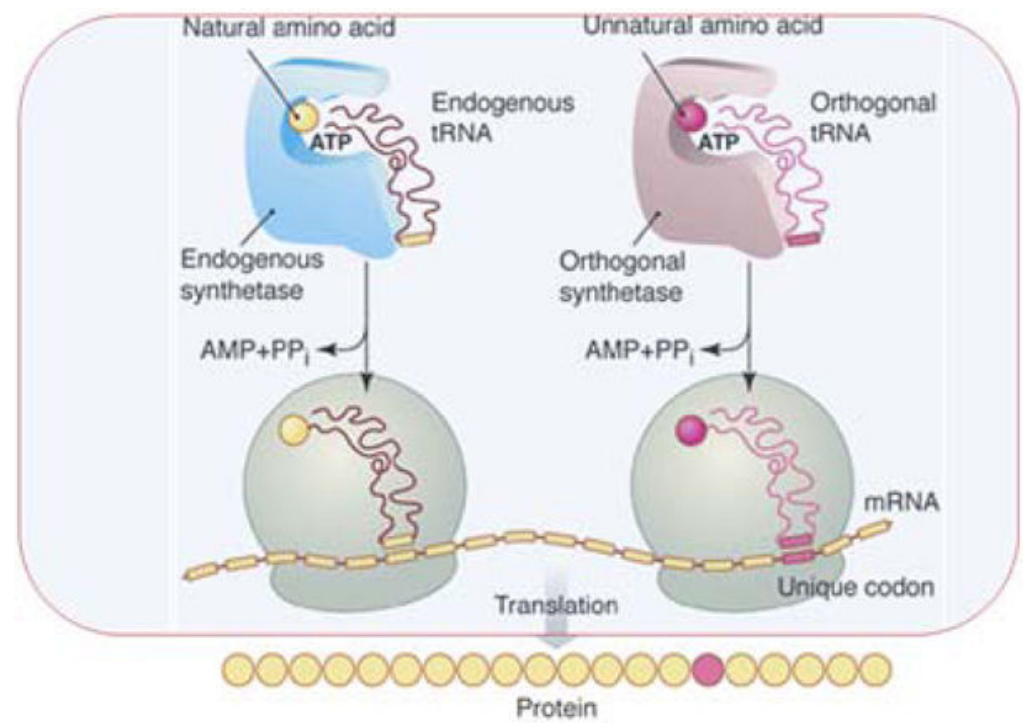

Figure 3.

Protein biosynthesis with an expanded genetic code (Courtesy Ambrx). 

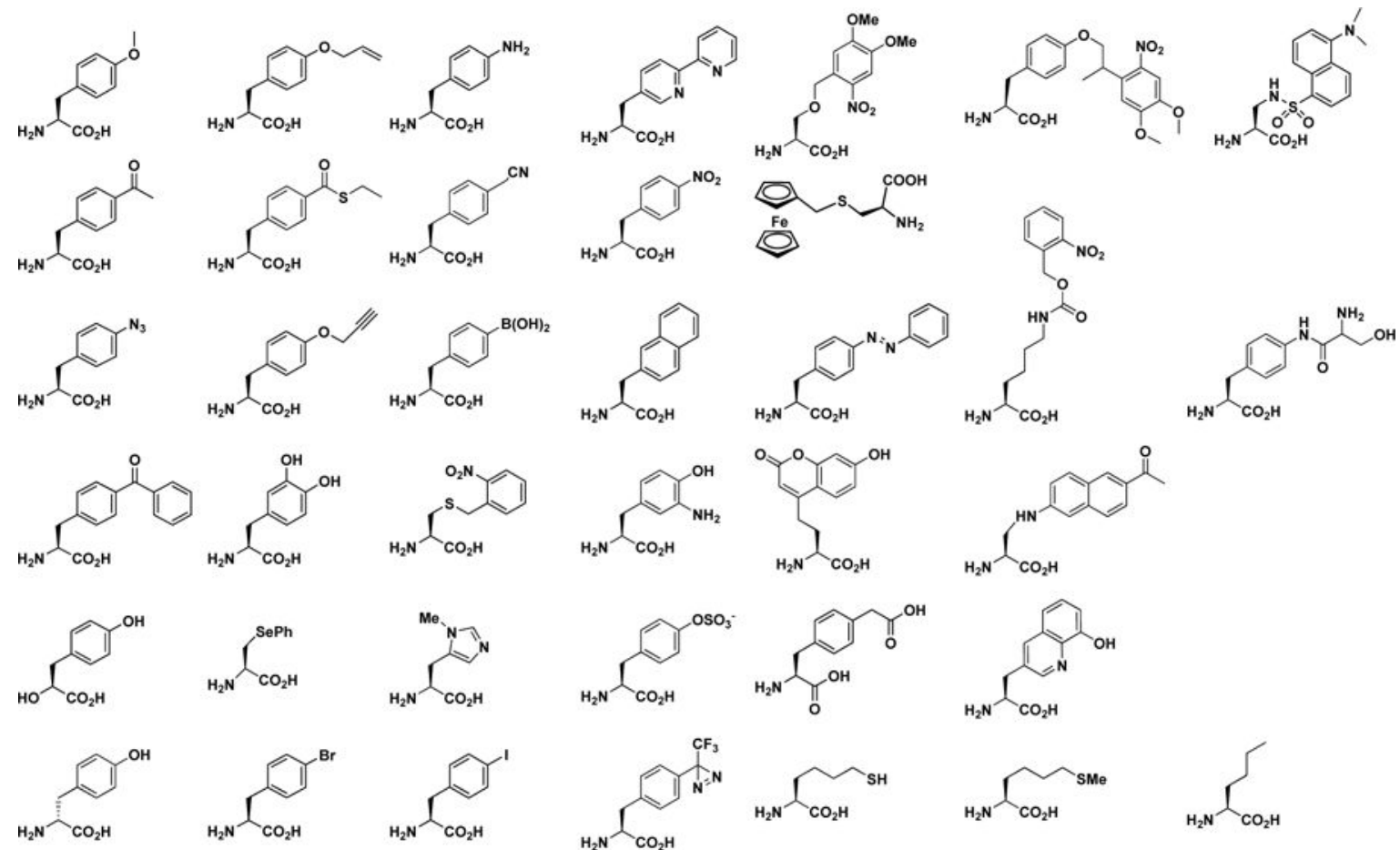

Figure 4.

An expanding genetic code - examples of unnatural amino acids that have been genetically encoded in prokaryotic or eukaryotic organisms ${ }^{13}$. 

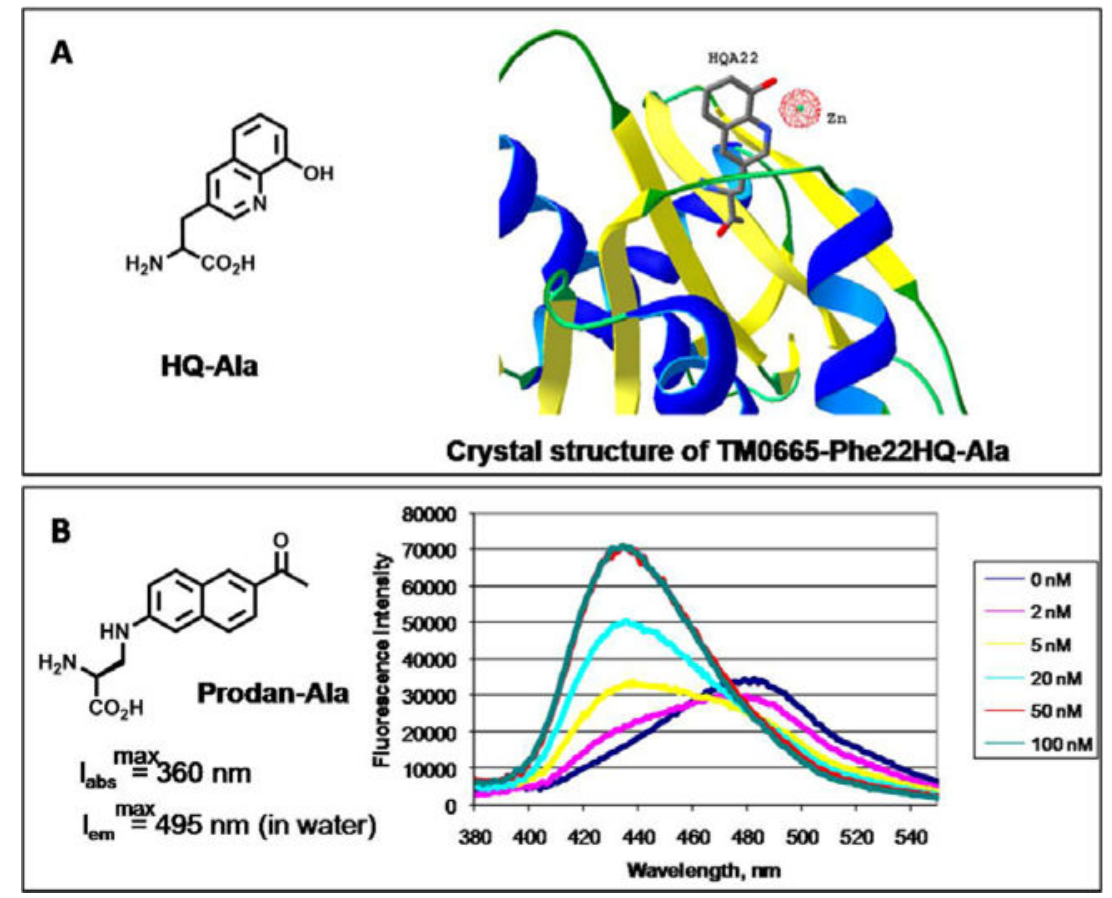

Figure 5.

A. Metal-ion binding amino acid HQ-Ala and crystal structure of TM0665 Phe22 $\rightarrow$ HQAla mutant. B. Fluorescent amino acid Prodan-Ala and fluorescence changes of an Asn160 $\rightarrow$ Prodan-Ala mutant of Glutamine Binding Protein upon addition of $\mathrm{Gln}^{147}$. 


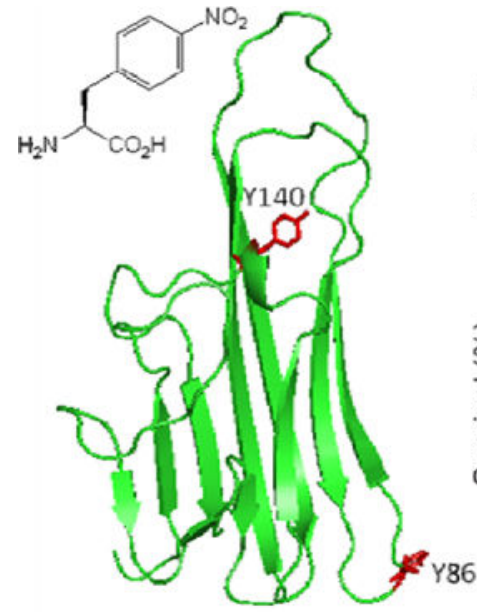

\section{LPS challenge:}

- Active immunization (5 $\mu \mathrm{g}$ antigen/mouse)

- 23C57BL/6 mice (age: 15 weeks)

- LPS dose $8.5 \mathrm{mg} / \mathrm{kg}$ on day 1

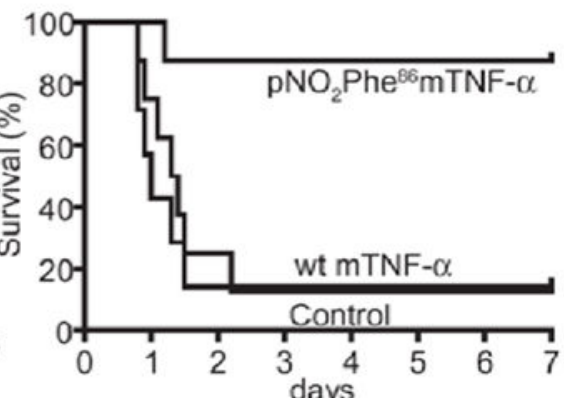

Figure 6.

Substitution of the immunogenic amino acid $p$-nitrophenylalanine for Tyr86 in murine TNF$a$ and subsequent vaccination leads to a robust T-cell driven immune response which cross reacts with wildtype TNF- $a$ and protects mice from LPS challenge ${ }^{143}$. 


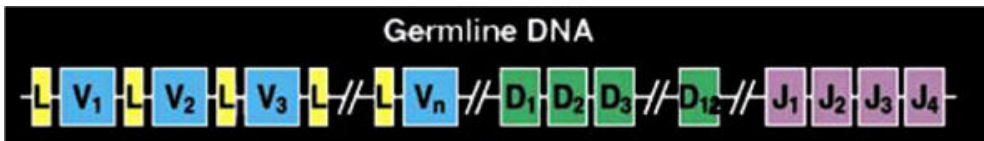

$\downarrow$ Gene Recombination

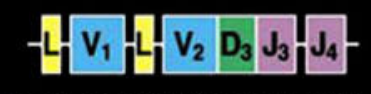

Rearranged Germline Gene

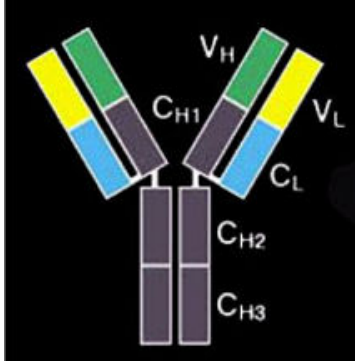

Germline Antibody

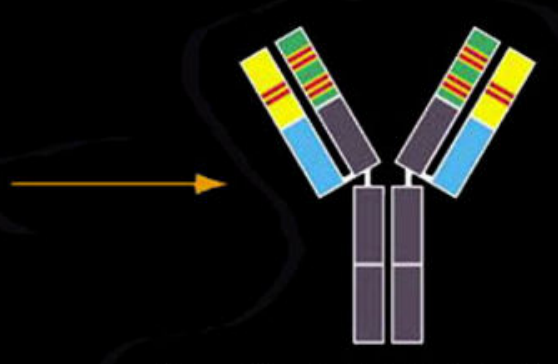

Somatically Mutated Antibody

Figure 7.

Combinatorial association of $\mathrm{V}, \mathrm{D}$ and $\mathrm{J}$ genes with recombination imprecision and subsequent somatic hypermutation during affinity maturation results in an enormous antibody repertoire capable of binding virtually any foreign molecule ${ }^{155}$. 


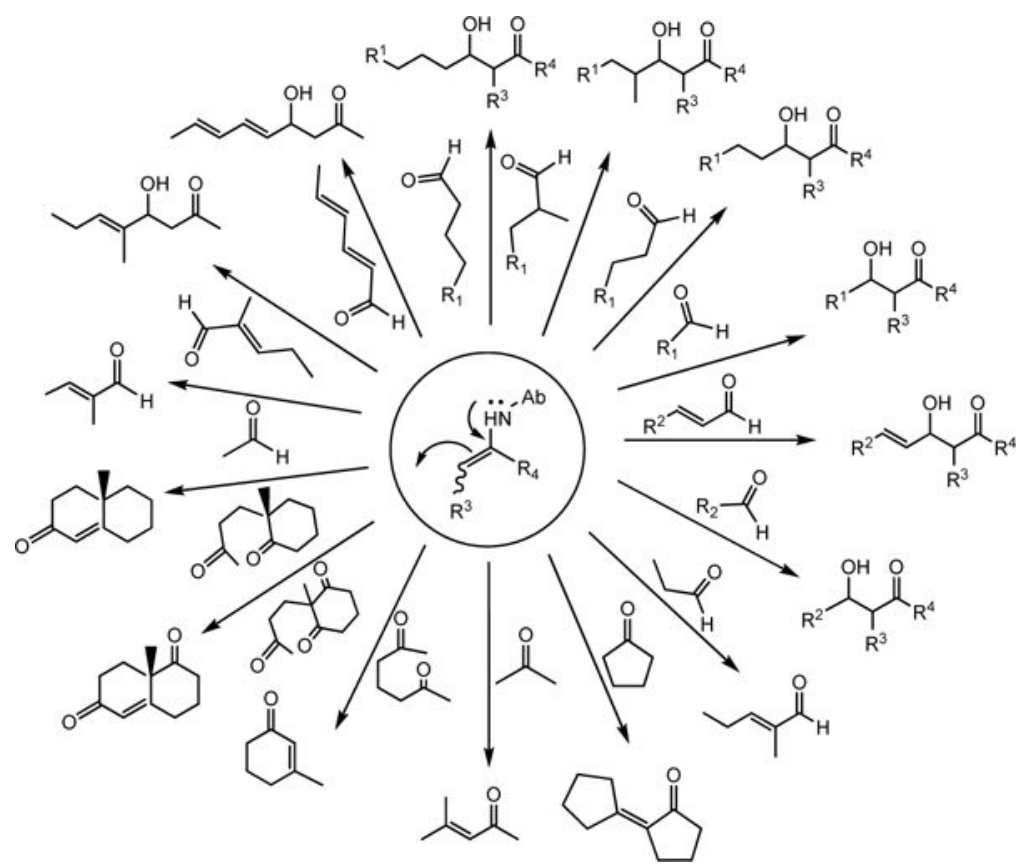

Figure 8.

A catalytic antibody with broad substrate specificity that catalyzes aldol reactions through covalent catalysis ${ }^{163}$. 


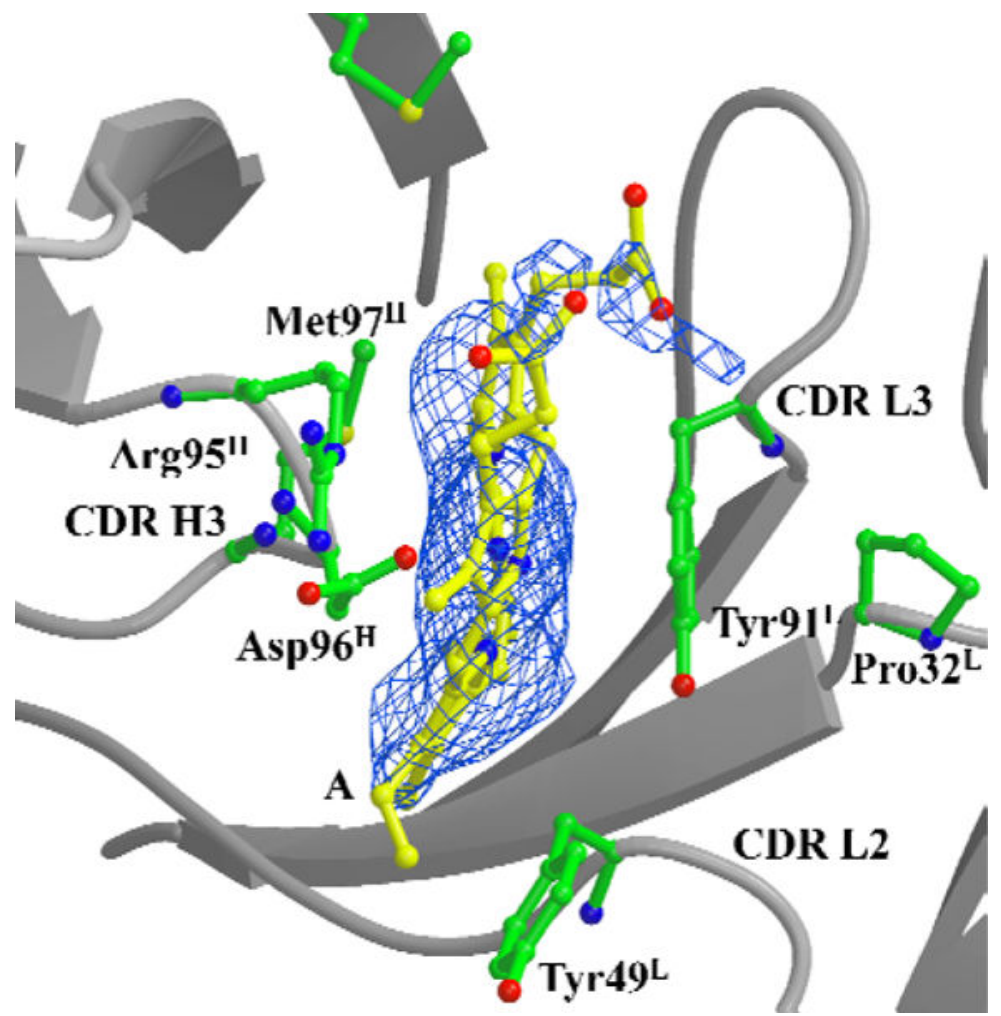

Figure 9.

X-ray crystal structure of the Michaelis complex of the strained mesoporphyrin substrate in a ferrochelatase antibody active site ${ }^{168}$. 


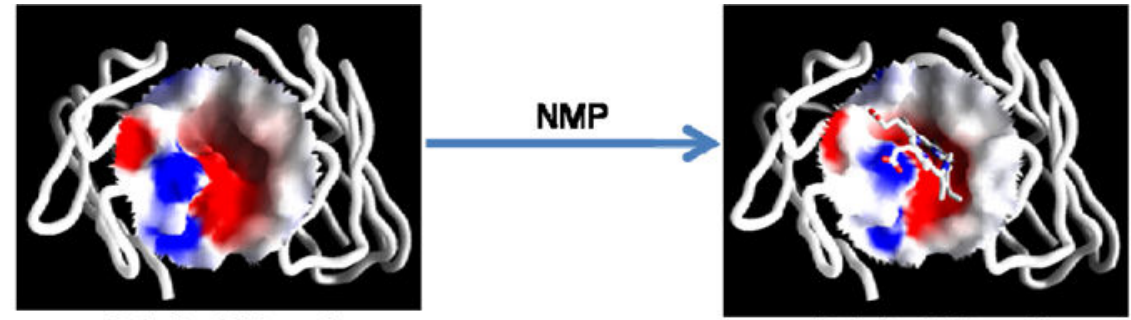

Affinity Matured
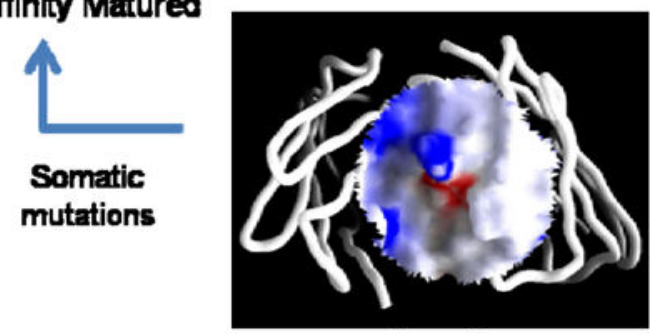

Affinity Matured

Somatic mutations

Germline

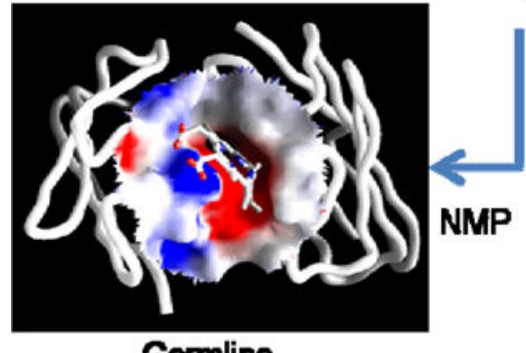

Germline

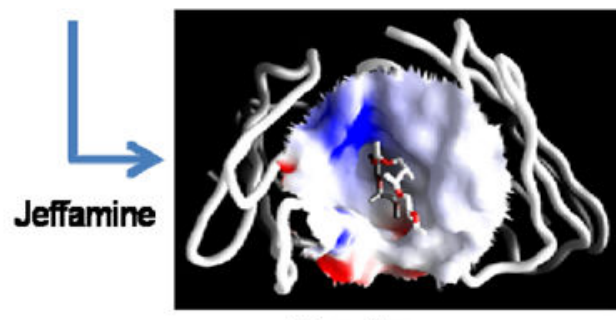

Germline

Figure 10.

Structural plasticity of a germline antibody that binds N-methylmesoporphyrin (NMP); somatic mutations during affinity maturation lock the optimal active site conformation ${ }^{170}$. 

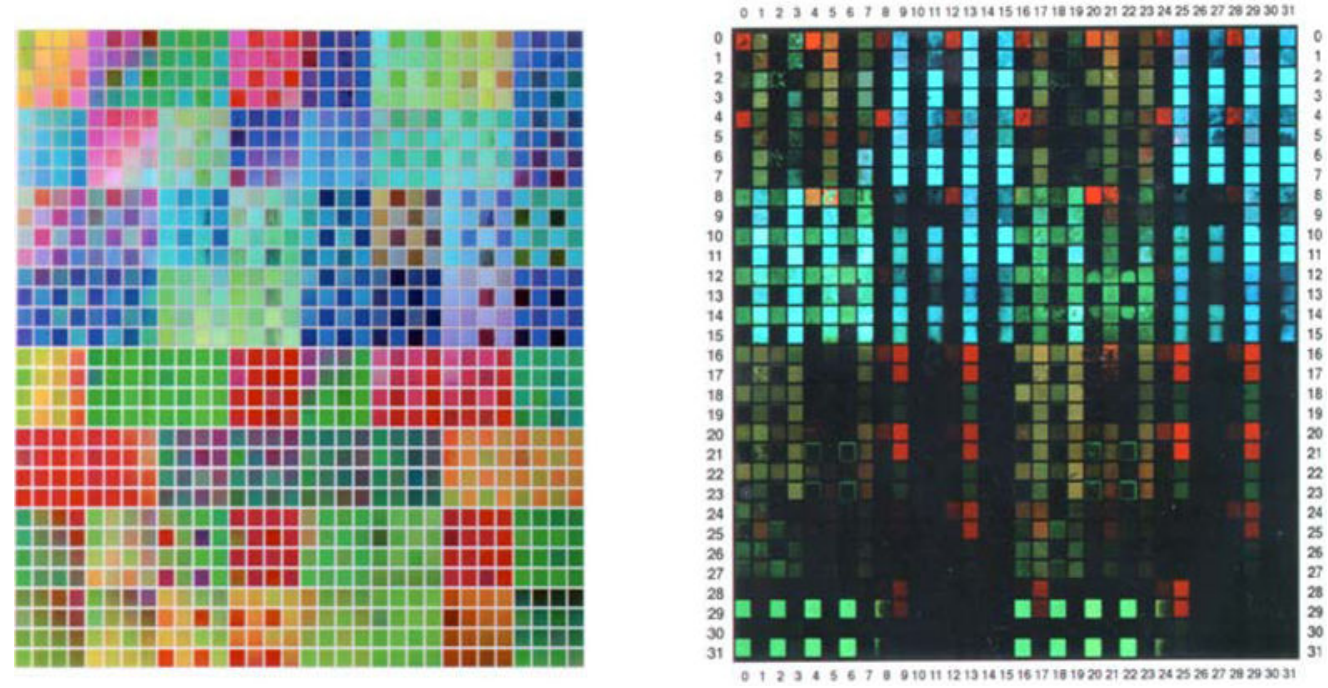

Figure 11.

A library of novel luminescent molecules generated by laser ablation of metal oxides through a series of physical masks ${ }^{205}$, under both ambient and UV irradiation. 


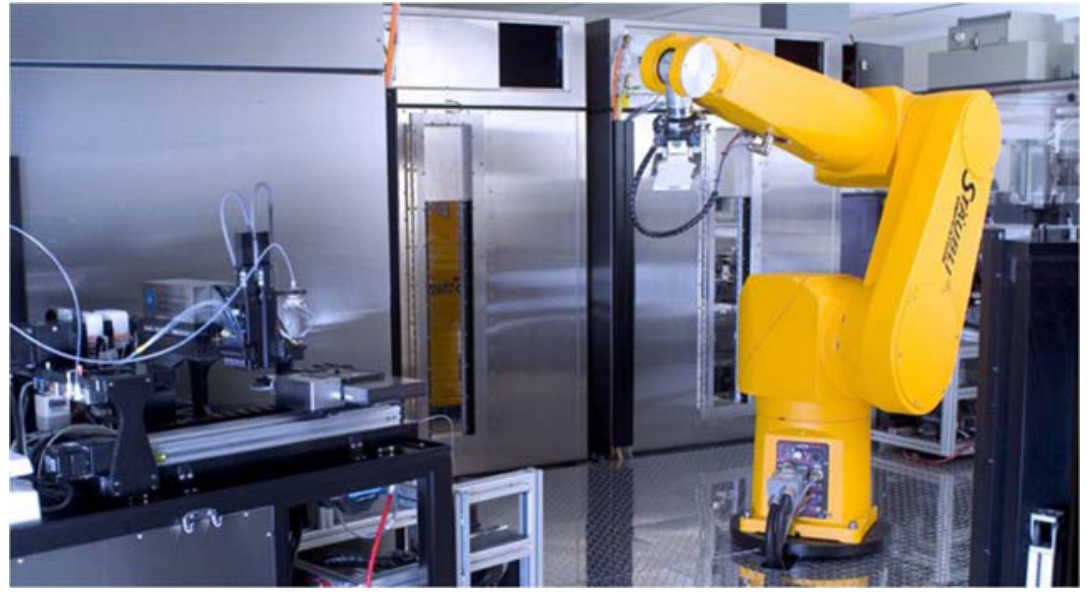

Figure 12.

Automated high throughput screening systems and chemical, genomic and protein libraries are enabling large scale, cost effective cellular screens; mechanisms should be found to make these tools available to moreacademic laboratories. (Courtesy GNF Engineering) ${ }^{224}$. 

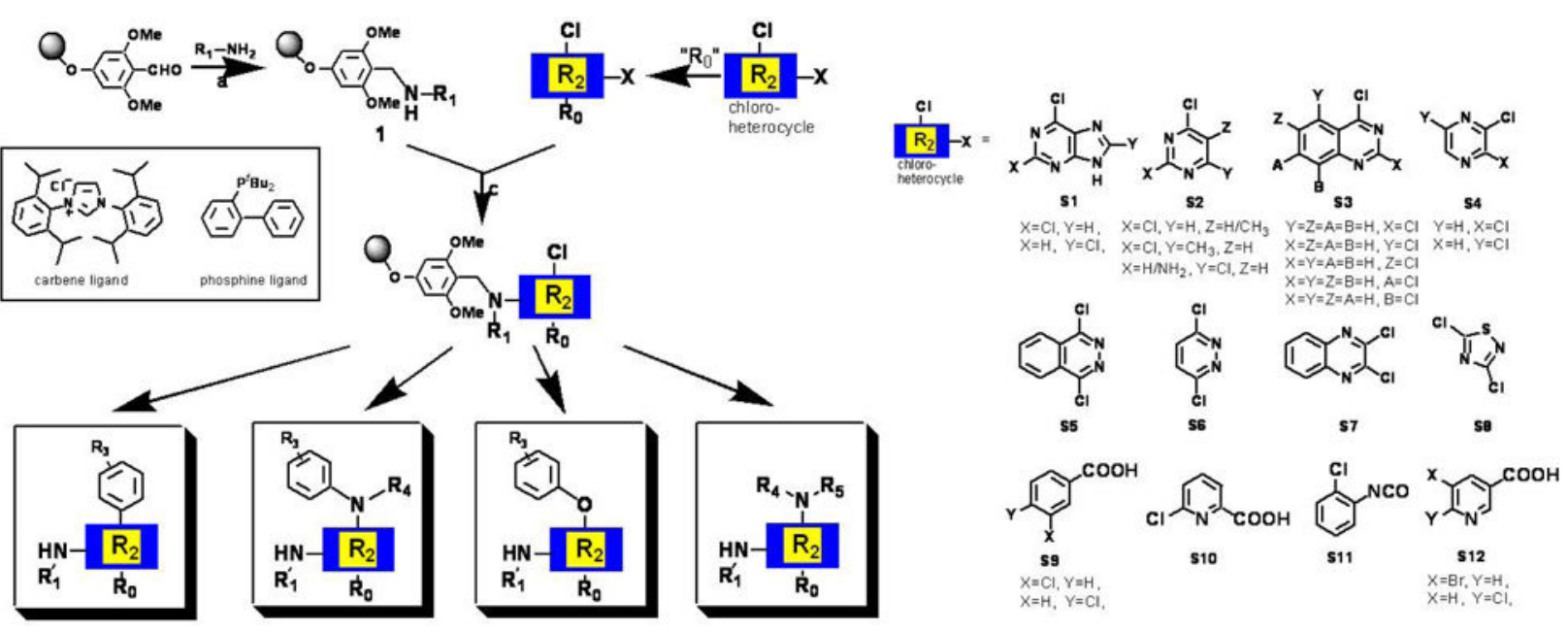

Figure 13.

An efficient synthesis of heterocycle libraries ${ }^{231}$. 


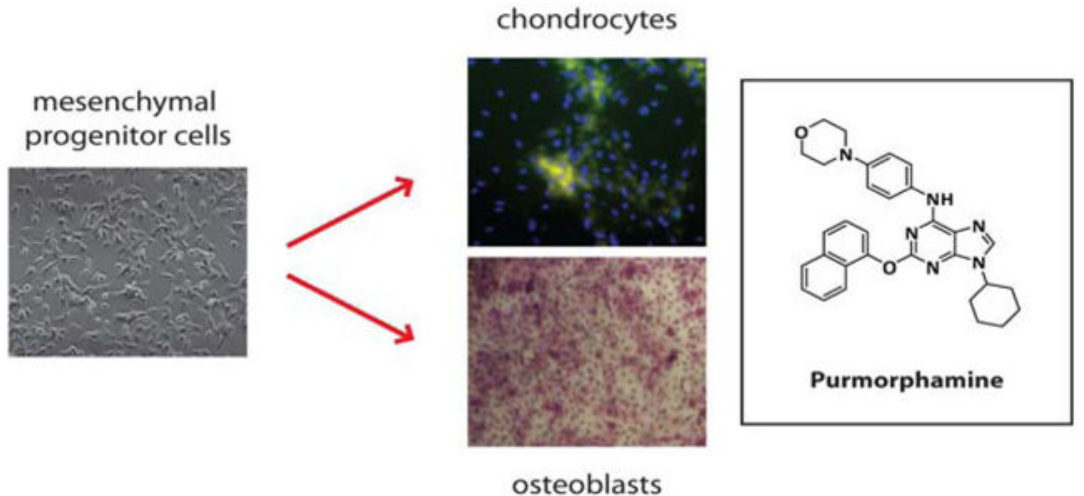

Figure 14.

Purmorphamine induces the selective differentiation of mesenchymal stem cells to osteoblasts by activating the Hedgehog signaling pathway ${ }^{253}$. 
A.

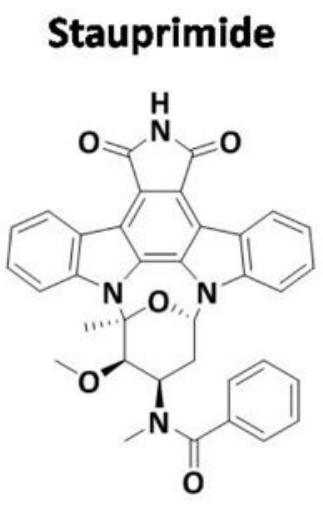

B.

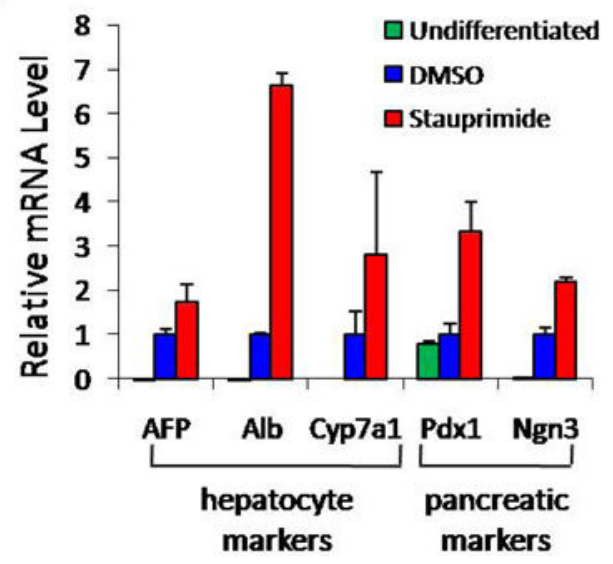

c.
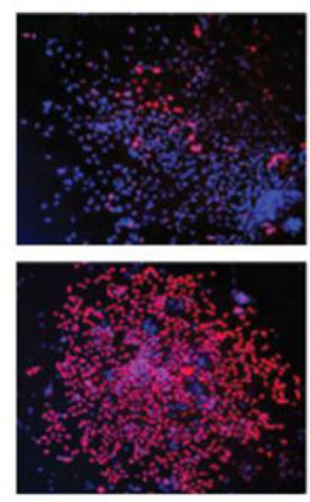

DAPI/SOX17

Figure 15.

(A) Stauprimide potentiates the differentiation of ES cells toward the definitive endoderm fate. (B) Mouse ES cells treated with stauprimide differentiate at high efficiency into endoderm-derived lineages, including hepatocytes (AFP, Albumin, Cyp7A1) and pancreatic precursors (Pdx1 and Ngn3). (C) Stauprimide also increases the differentiation of human ES cells into definitive endoderm ${ }^{271}$. 

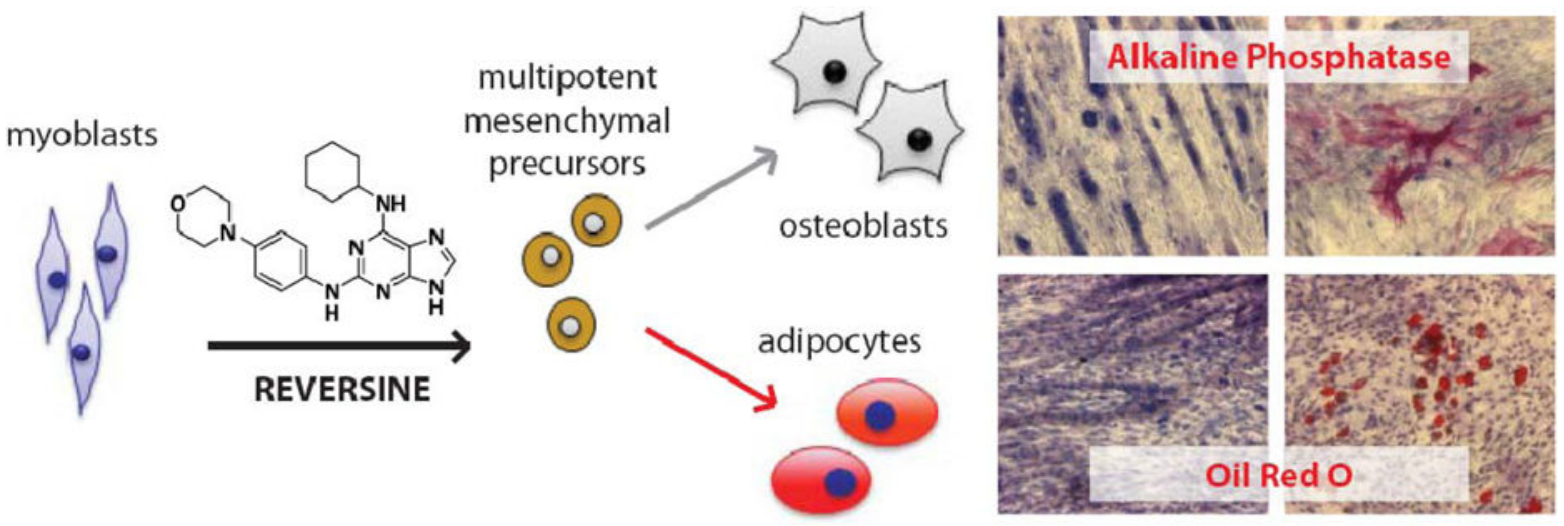

vehicle

reversine

Figure 16.

Reversine reprograms myoblasts (which normally differentiate into myotubes) to precursor cells that can be differentiated into osteoblasts or adipocytes 280,281 . 


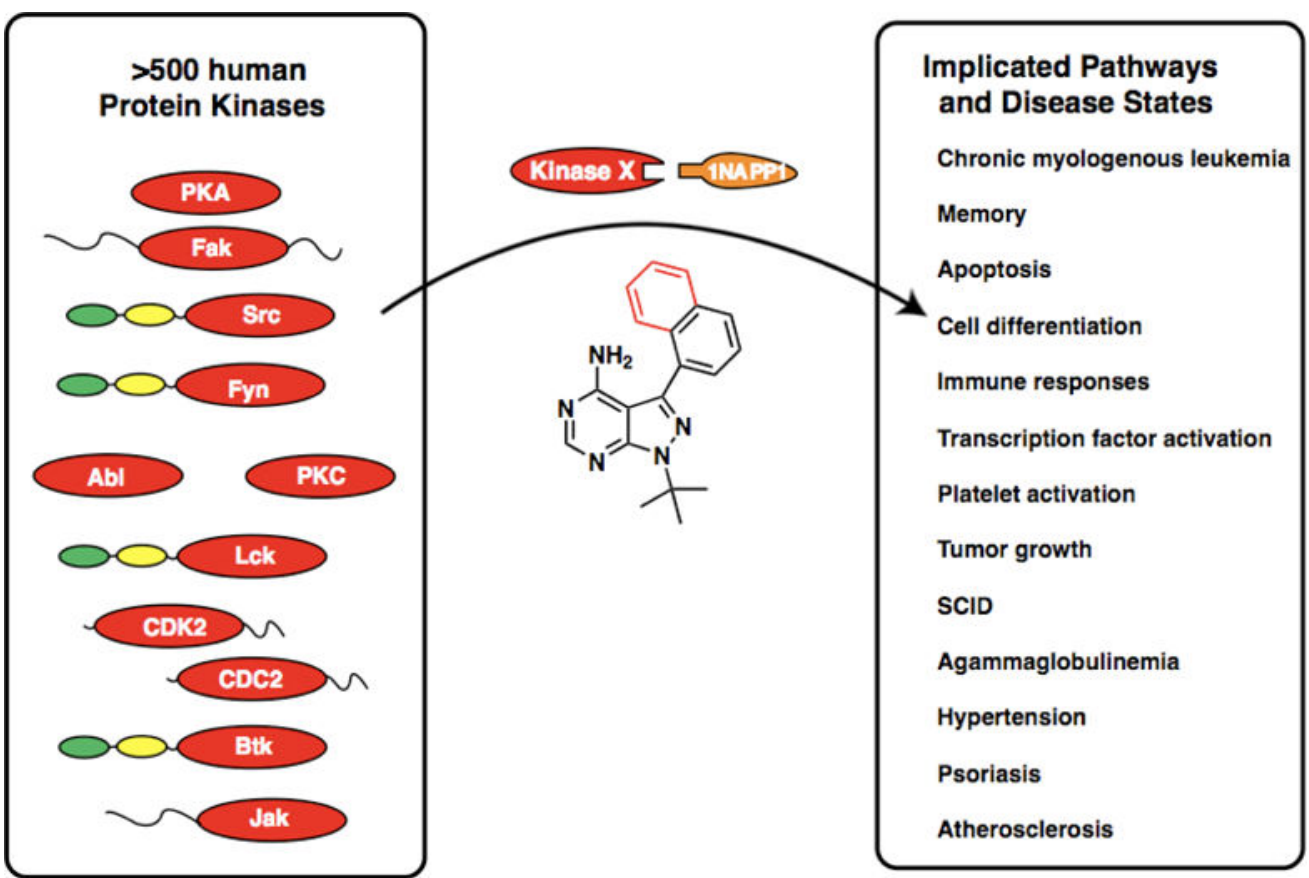

Fig 17.

A kinase of interest can be genetically engineered to be selectively inhibited by an orthogonal kinase inhibitor which does not inhibit any wild-type protein kinases. The conservation of the ATP binding pocket across the kinome provides generality to the approach as the residue which must be engineered is conserved ${ }^{33}$ (Courtesy Kevan Shokat). 

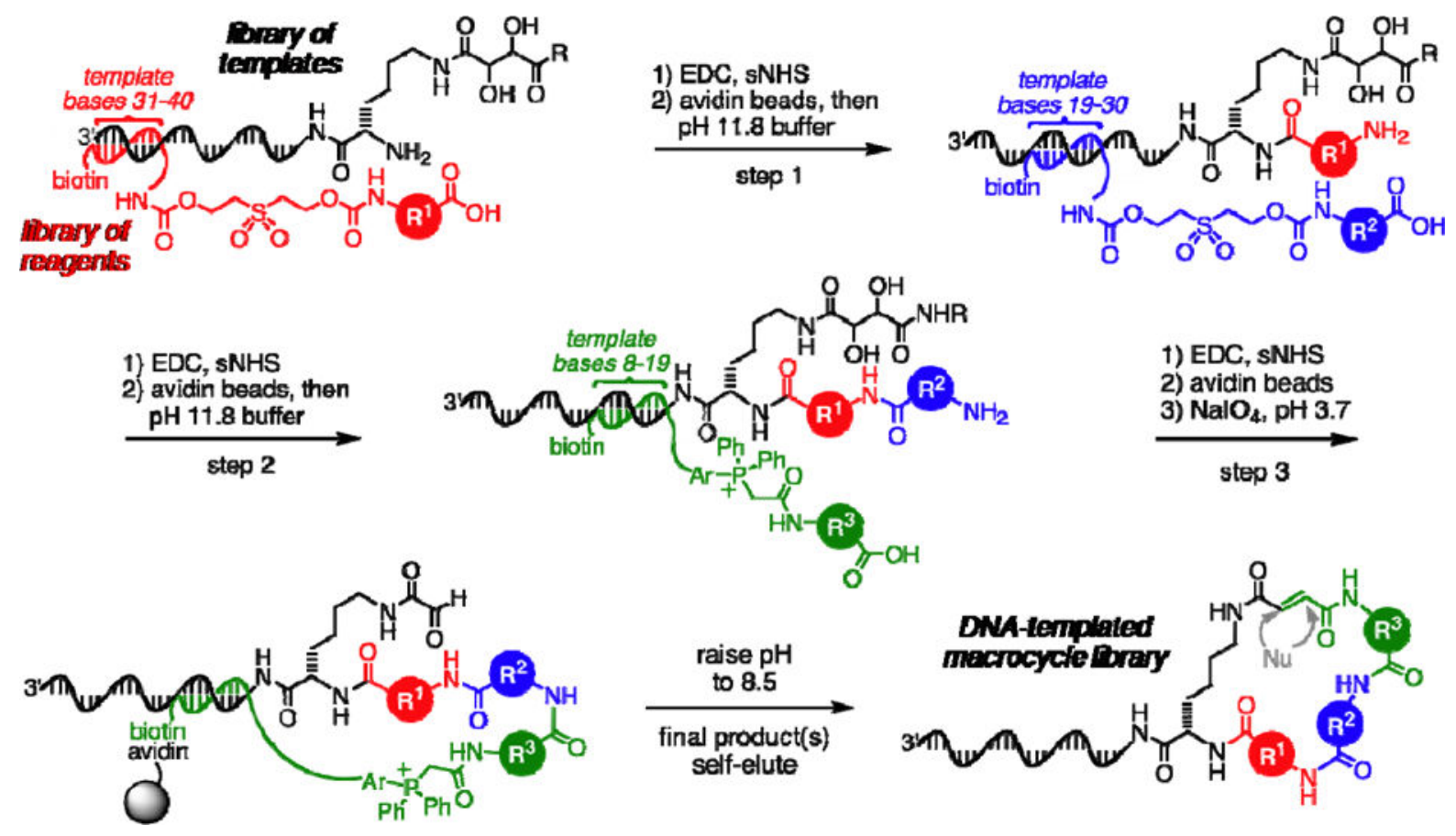

1) EDC, sNHS

2) avidin beads

3) $\mathrm{NaIO}_{4}, \mathrm{pH} 3.7$

step 3

Figure 18.

The template directed synthesis of libraries of macrocycles ${ }^{28,304}$ (Courtesy David Liu). 

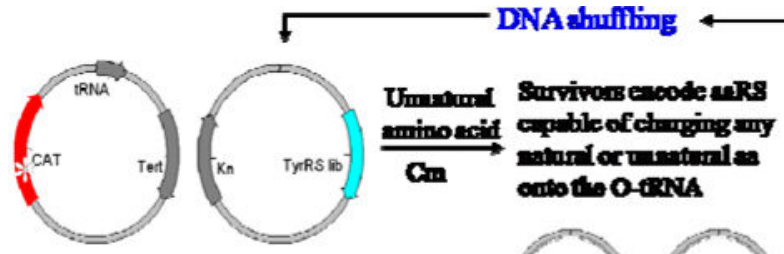
minoscid Crpible of changing my

Cm

enturi or uneturilen

ontoto O-TRIA
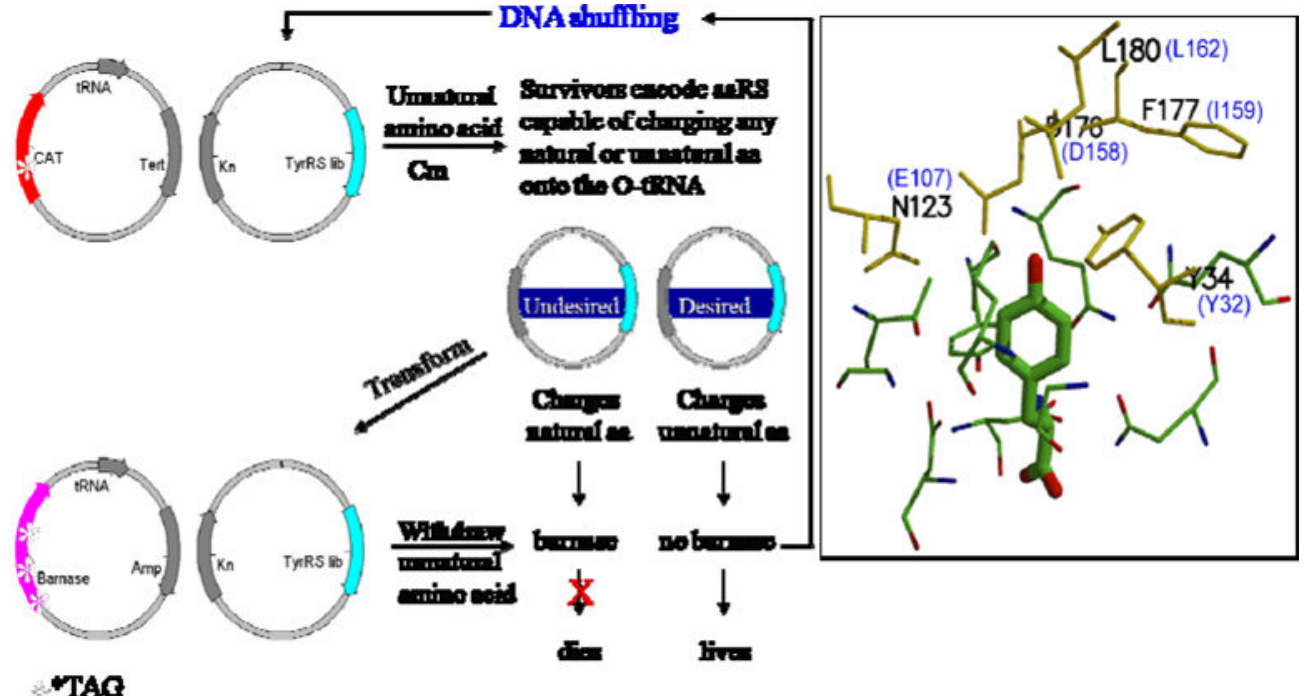

Scheme I. 